\title{
Language Ideology and the Colonial Legacy in Cameroon Schools: A Historical Perspective
}

\author{
Genevoix Nana \\ Correspondence: Genevoix Nana, Faculty of Education and Language Studies, The Open University, Walton Hall, \\ Milton Keynes, MK7 6AA, UK.
}

Received: December 9, 2015 Accepted: December 30, 2015 Online Published: February 16, 2016

doi:10.11114/jets.v4i4.1385

URL: http://dx.doi.org/10.11114/jets.v4i4.1385

\begin{abstract}
Cameroon prior to colonization had many languages, with none having precedence over the other. With the development of trade and the installation of missionaries along its coast, a number of local and European languages gained prominence. English became the most widely used western language. It established itself as the language of trade and of the court of equity while some local languages and Pidgin English were standardized and used in evangelization. With the triple presence in succession, and concurrently, of the German protectorate, the British and the French administrations, the ideology of 'one nation, one language' that developed in eighteenth century Europe was pursued, with varying degrees of effectiveness, in Cameroon by these administrations. This ideology was applied with resolve in education, mostly by the French rule, and made an impact on pre- and post-independence Cameroonian authorities who adopted English and French as official languages of the country.
\end{abstract}

Keywords: language ideology, linguistic imperialism, language policy and planning, language education, official biculturalism and multilingual education

\section{Introduction}

According to Breton and Fohtung (1991) Cameroon has about 248 languages spoken by an equally diverse ethnic population. The country's name originated from the Portuguese word Camarões (prawns) around 1472 when Portuguese visited the Wouri estuary. Since then, the name mutated in accordance with the various colonial and postcolonial administrations of the country, while Cameroon's historiography during the colonial era and beyond has been authored in relation to colonialist and imperialist underpinnings. The rendering of the country's name, in its various orthographies during the colonial period, from Kamerun (German) to Cameroons (British) and Cameroun (French), apparently highlights a visualization of each imperialist rule and the underlying mission pursued by them. It is not surprising therefore that the language policy applied in education by these colonial administrations differed significantly. Reynaud-Paligot (2006) suggests that the moral principles underpinning colonialism might have justified the difference in the application of colonial policies between imperial powers while White (1996) points out that such difference reflected the agenda of mostly the French and British administrations which was that of assimilation and indirect rule. Before colonization, however, the language situation of Cameroon was far from being marked by an ideological denomination between 'language' and 'dialect' as such designation became institutionalized during colonial times.

\section{Linguistic Imperialism and Language Ideology in Europe as a Prelude to Colonization}

While colonialism consists of the occupation of a place (the term colony comes from the Latin word colonus, which means farmer) ${ }^{1}$, Harmand (1910) argues that imperialism (the word originated from the Latin term imperium, which means to command) which is the ideology underpinning such occupation, endows it with a civilizing mission (see also Marchand, 1971 and Conklin, 1997). However, in its rationalization, imperialist ideology was perceived by some as a moral predicate rather than presupposing a confrontational rapport between the 'civilized' and the 'savage' (Hardy, 1917). In the theorization of imperialism, the colonizer's language was, in most cases, conceived as the supreme medium for the mediation of its ideologies and the subjugation of the colonized.

Ideology refers to a 'science of ideas'. The term was coined in 1796 by French philosopher Antoine Destutt de Tracy who thought that ideology would reveal people's unconscious habits of mind. Ideology thus relates to the very habits of mind, beliefs, assumptions, expectations, which govern the life of an individual or a group and which often are superimposed on the world in order to give it structure or meaning. It serves to direct political, economic or social 
activities and could be conceived of as a doctrine or belief system; a system of presentations that explicitly or implicitly claim to absolute truth. In the field of linguistic anthropology, the link between language and ideology is conceived as 'the cultural system of ideas about social and linguistic relationships, together with their loading of moral and political interests' (Irvine, 1989, p. 255).

This study examines language ideology from the perspective of the 'one nation, one language' model of language and identity that developed in Europe in the eighteen century. ${ }^{2}$ This model is a construct, given that there was no linguistic uniformity in countries like Britain and France around that time, even though, in the case of France and Germany, there was a move towards language uniformization through education and the inculcation of a common sense of identity and loyalty to the state highlighted by the use of one language (Orosz, 2008, p. 1). Nowadays, in these supposedly monolingual countries there are varieties of the same language and language ideological discourse has led to social categorizations on the basis of language use. Such social ascriptions have been transposed in education settings where the promotion of a standard language, perceived to be the variety of the mainstream cultural group, is encouraged. In multilingual contexts like Cameroon, where colonizers transposed their ideologically mediated common-sense about the West with regard to language uniformity and where former colonial languages have been adopted as official languages, language ideology has consisted in a discourse of utilitarianism, unity and globalization and the resultant marginalization of local languages. This work seeks to explore the development of language ideological discourse underpinned by the concept of 'one nation, one language' in eighteenth century Europe and how this concept was exported to colonial Africa and Cameroon where different colonial administrations provided rather dissimilar approaches to the implementation of their language in education policy. The dissimilarity in language policy application reflected colonizers' underpinning linguistic ideologies and suggests that in French Cameroon such policy was largely assimilationist while in British Cameroons it was accommodative of local languages.

\subsection{One Nation, One Language}

At a political level, linguistic ideology construes nationhood and citizenship as predicated on language. ${ }^{3}$ The link between language and nation is such that it could be argued that a nation which is not defined or identified by the language that her people speak does not fundamentally exist. This link is to be traced back to the days of the Roman Empire and the use of Latin for the glorification of the Roman culture and influence. Patten traces the idealization of nationhood as predicated on language to sixteenth century French poet Joachim Du Bellay. In his La défense et illustration de la langue française Du Bellay purported that Rome's language was ultimately a more effective and glorious kind of fortification than all its buildings and palaces. In the eighteenth century, three German philosophers of the romantic nationalist school- Johann Gottfried Herder, Wilhelm von Humboldt and Johann Gottlieb Fichte formulated an influential theory of nationalism that established language as a crucial condition of individual well-being and political legitimacy. Herder viewed the relationship between nation and language as filial and argued that 'to deprive a people of its speech is to deprive it of its one eternal good... with language is created the heart of a people' (Herder, 1783, cited in Carlton, 1928, p. 53). Nonetheless, Herder's conception of the link between language and nation was far from being essentialist and rather presupposed a relationship that was characteristic of linguistic identity, in the sense of an intrinsic attachment-devoid of any ideological fundament-to one's native medium. Ethno-cultural nationalism à la Herder as propounded by Berlin (1976) implies the uniqueness of each culture as a reflection of humanity in its diversity. It does not bemoan multiculturalism or multilingualism and could find some theorizing likeness in the 'unity in diversity' conceptualization. By the way, given that language use is inclusive and exclusive at the same time, it becomes tenuous to deliberate on its being atonal, as any language is the vehicle of a culture that it mediates. By the close of the eighteenth century, a series of movements aimed at reviving, standardizing, enriching, and eventually making dominant historically spoken dialects of regional populations first took shape in the southern, northern and eastern peripheries of Europe and continued through the nineteenth century and well into the twentieth (Woolard and Schieffelin, 1994). ${ }^{4}$

Studies investigating the representation of language as an ideological construct for nationhood have often found that a people's claim to political autonomy is related to a common language and a shared culture (Levy, 1929, 1950). ${ }^{5}$ In the context of this study, it becomes relevant to explore how the rhetoric of 'one nation, one language' was highlighted in the construct of a French nation and how the extension of this construct in Cameroon under French mandate and trusteeship impacted on the language policy applied by the French administration. This rhetoric projected French as a unifying factor and as a catalyst for the nation (Judge, 2007, p. 22). It is argued that 'in France, the search for self-identification led to a reification of France itself as a natural and indivisible entity' (Blommaert and Verschueren, 1998, p. 197). The many laws taken by France to consolidate French as the only unifying language of the country also contributed to the suppression of other languages and dialects spoken in France (Jaffe, 1999, 2001). ${ }^{6}$

Contrary to France, where French is the de jure language of the country and education anchored to the republican principles ${ }^{7}$ of liberty, equality and fraternity, English is the de facto language of England and education was originally 
founded on faith and trust in a monarchic system fraught with class division and inequality (Spens, 1938; Gates, 2004; Chitty, 2007; Gillard, 2011). The difference between the French $3^{\text {rd }}$ Republic and the English monarchy at the close of the eighteenth century is thus stark with regard to the value attached to language and religion and the symbolic power assigned to these two social phenomena in the control of the masses. Unlike in the French Republic where schooling was conceived as the training of the masses to adhere to republican ideals, in England education appeared to be the prerogative of the elite and the schooling of the masses was apparently limited to the understanding of the basics (three and then four 'Rs': Reading, Writing, 'Rithmetic' and Religion) that enabled them to serve the elite (Hadow, 1923, p. 22; Gordon and Lawton, 1978, p. 187; Chitty, 2007, pp.15-16). Religion ${ }^{8}$ played a greater role in achieving social regulation in England than the English language which was not really perceived as a significant force in the legitimization of the monarchy (Eagleston, 1996, pp. 20-24; Innes, 1987; Williams, 1961). ${ }^{9}$ Out of Britain, in the colonization of India, Viswanathan (1998) argues that English was used as a medium through which the law of social order and morality was inculcated to the colonized as the British administration avoided assigning this role to religion for fear of offending the Indian people, the majority of whom believed in Hinduism. Education through English was seen as training an elite class and acculturating them to the English culture, with the ultimate goal, in the long term, that the elite's accommodation to the English language and culture would influence the masses, make them abandon Hinduism and convert to Christianity (Mahmood, 1895, p. 50; Trevelyan, 1909, p. 330; Mahadeo, 1999).

The language in education policy applied by Britain and France in Cameroon was therefore influenced by the perception of the role of language and religion in the shaping of an English and French consciousness through education and, in the case of British colonial policy in Africa, by the experience of introducing English as a medium of instruction in education in the colonization of India.

\section{An Overview of the Language Situation in Pre-colonial Cameroon}

Ante-colonization Cameroon was a mosaic of people speaking many languages (see Figures 1 and 2 below for a representation of the language groups of Cameroon). Among these languages, Shumum ${ }^{10}$ was standardized by Sultan Njoya and used for teaching long before the arrival of western missionaries while Fulfulde had been used for the dissemination of Islam in the three northern regions of Cameroon as far back as the seventeenth century (Breton and Fohtung, 1991, p. 20; Echu, 2004). ${ }^{11}$ The privilege enjoyed by Shumum and Fulfulde as media of instruction and religious languages was to be challenged with the arrival of missionaries around 1840. They standardized languages such as Duala, Bali, Ewondo, Bulu, Isubu, Mungaka and Pidgin English ${ }^{12}$, translated the Bible in some of these languages and used them for evangelization and instruction (Mbassi-Manga, 1973; Kouega, 2008). Pastor Joseph Merrick, from the Baptist Missionary Society of London, was the first missionary to arrive Cameroon in $1843 .{ }^{13} \mathrm{He}$ opened Cameroon's first primary school in Bimbia in 1844 where English was used as the language of instruction (Joseph, 1980; Atayo, 2000; Ihims, 2003; Che, 2008). In 1884, other Baptist missionaries such as Saker and Johnson also arrived and opened a second English medium school in Douala (Fonlon, 1969; Todd, 1983; Vischer, 1915). ${ }^{14}$ Todd (1983) indicates that between 1843 and 1884 Baptist missionaries had established 24 mission stations, each with a vernacular school. According to Vernon-Jackson (1967, p. 6), American Presbyterian missionaries arrived in 1879, started their mission in Batanga and opened schools where English and the Bulu language were used. Apparently, English was the first western language to be introduced in education in Cameroon by the missionaries. ${ }^{15}$ While the pre-colonial period could be considered as the bliss age of language cohabitation, with English, Pidgin English and some Cameroonian languages enjoying a relative status as media of instruction in schools, language of the administration and lingua franca for trade and evangelization, language conflict soon set in with the start of the German rule. 


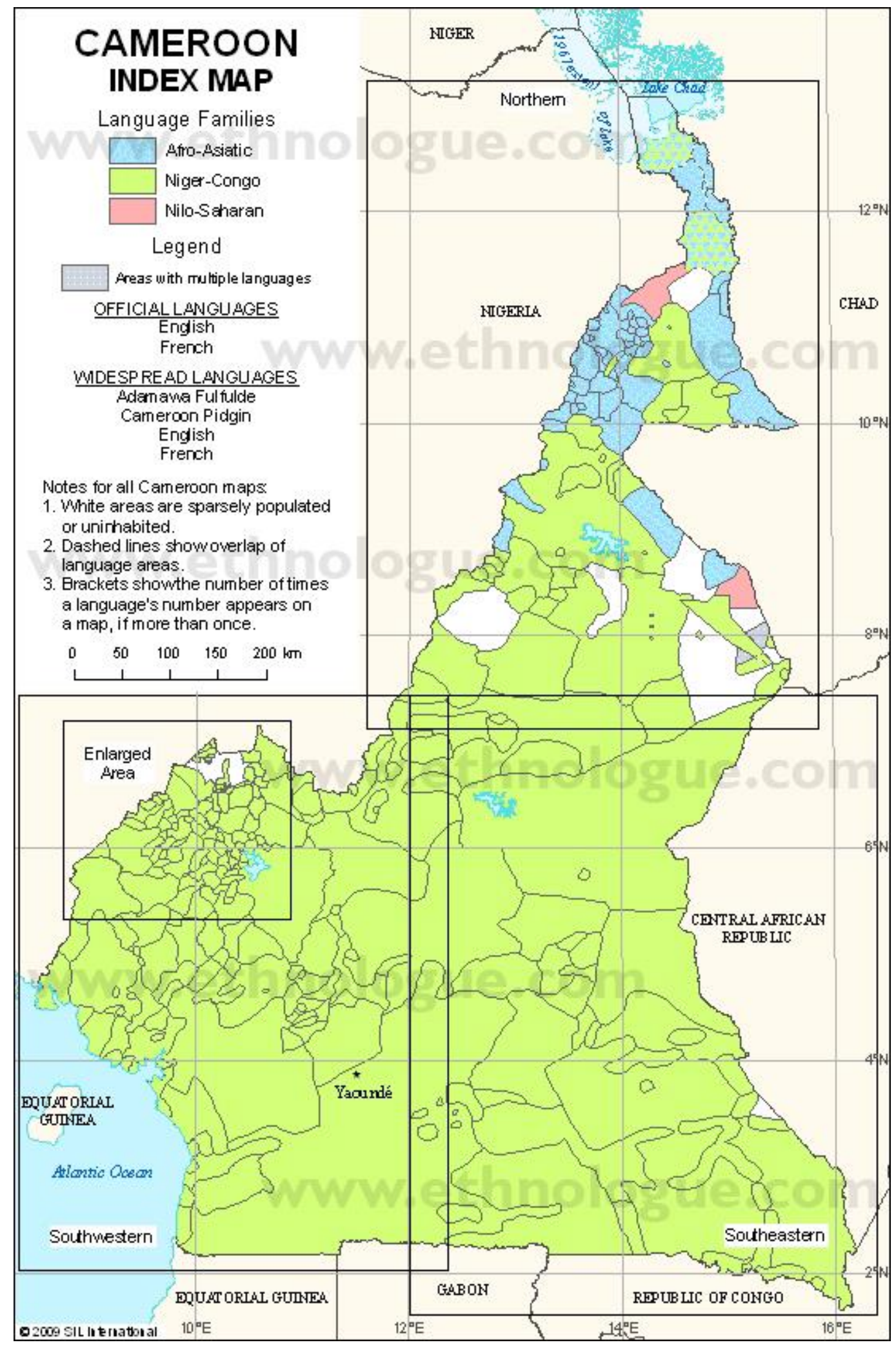

Figure 1. Cameroon language families and groupings, Source: (Lewis, 2009).

Retrieved from: http://www.ethnologue.com/16. 


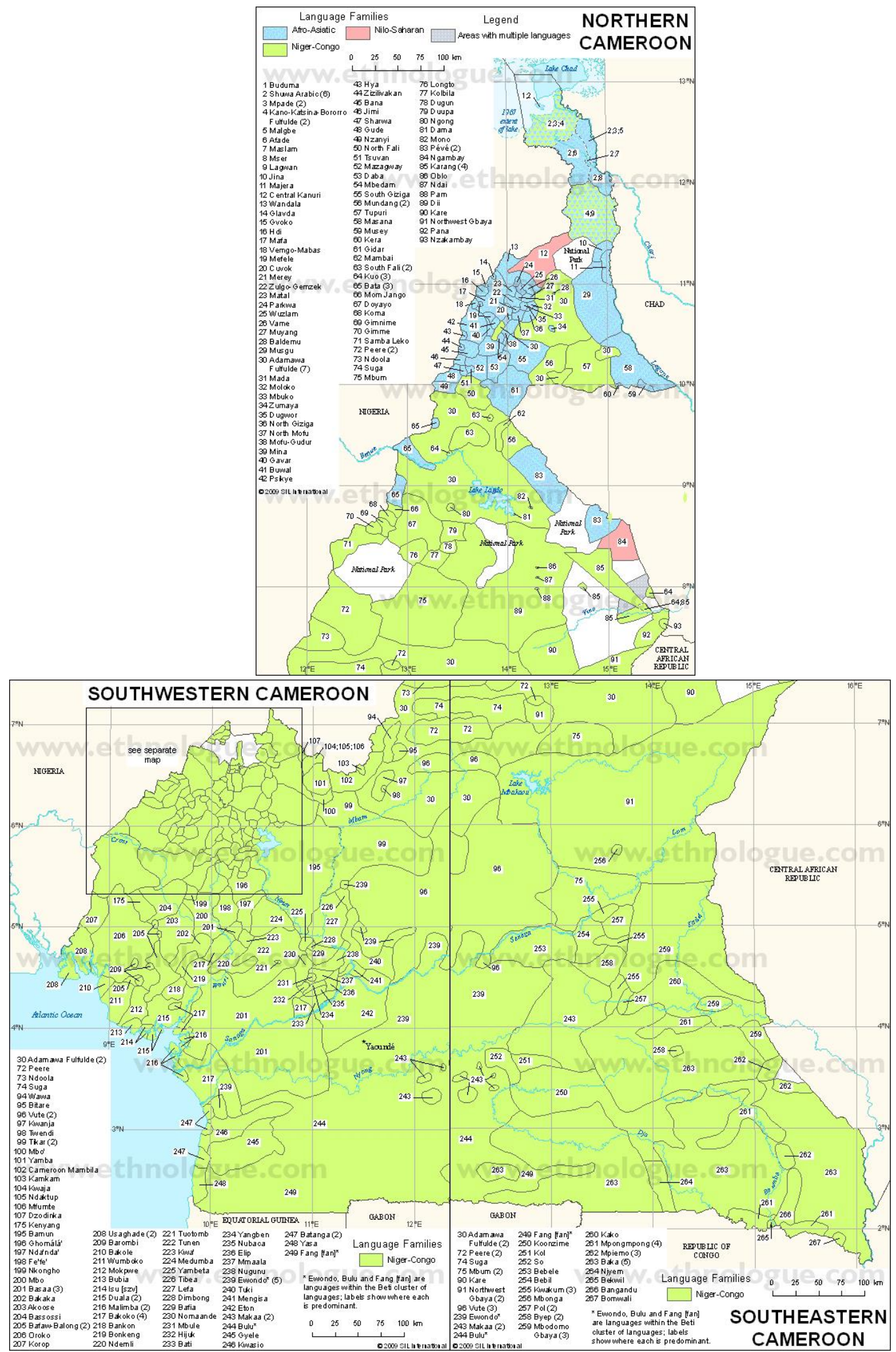

Figure 2. Cameroon language groups, source (Lewis, 2009). Retrieved from: http://www.ethnologue.com/16.

\section{Language Policies and Ideologies in Education and the Public Sphere During Colonization}

4.1 German Cameroon (1884-1914)

Initially the dominant power along the Cameroon coast, Britain was however supplanted by Germany. On the 12 July 1884, Gustav Nachtigal, the plenipotentiary of German Chancellor Otto Von Bismarck, signed a treaty with Kings Bell and Akwa of Douala establishing German rule over the country. On the 14 July he hoisted the German flag in Douala, 
making Kamerun ${ }^{16}$ a Schutzgebiet (protectorate) of the Kaiser's Reich. Atangana (1996, p. 86) points out that the German colonial administration's policy in Cameroon was mostly based on morally conditioning the colonized to submit to forced labour. Chiabi (1997, pp. 2-10) concurs with Atangana as he indicates that the Germans used conscription and imposed labour tax on the population in order to create plantations and build roads and railways necessary for the ferrying of plantation products and the country's natural resources (see also Gardinier, 1867; Rubin, 1971; O’Neil, 1996). ${ }^{17}$ To achieve this, the German administration mainly relied on traditional rulers who collected labour tax on their behalf and supplied them with conscripted men (LeVine, 1964; Nkwi and Warnier, 1982). ${ }^{18}$ Religion played a crucial role in achieving this as it was used as an instrument of German cultural expansion, given that the Germans considered colonization to be a missionary action and Bismack initially viewed the administration of Germany's possessions overseas as a matter of private enterprise (Rudin, 1938, pp. 353-354; LeVine, 1964, p. 71; Erb, 1967; Quinn, 1989, pp. 94-97; Orosz, 2008, p. 6). ${ }^{19}$ Whitehead (2007) notes that schooling was mostly vocational and trade training and, as such, tailored to the needs of the colonial administration's development agenda.

\subsubsection{The Language Situation in German Cameroon}

At the start of German administration in Cameroon, functional communication was in English and English and some local languages were being taught in the 24 vernacular and five English medium schools founded by the English Baptists and the American Presbyterians. The Germans thus found it difficult to address the language issue immediately as their administration also used English while waiting to implement a language policy germane to their rule (Joseph, 1980, p. 9; Fonlon, 1969, p. 31). Vischer (1915, p. 130) observes that London Baptist missionaries eventually had to hand over their missions to the Swiss-German Basel Mission in 1885 because of the acrimony of the German administration. The American Presbyterians were allowed to stay only if they switched to the use of German in all their activities (Rudin, 1938; Eyongetah and Brain, 1974, p. 78). In 1890, German Catholic Pallottines missionaries arrived, followed in 1891 by the German Baptists. ${ }^{20}$ In 1887, the first German education officer, Theodor Christaller, arrived and opened a government school in Douala (Calvert, 1917, p. 57). Four more government German medium schools were opened over the years in Victoria ${ }^{21}$, Buea, Garoua and Yaoundé (Wolf, 2001, p. 59; Vernon-Jackson, 1967, p. 11).

In 1897, Governor Von Puttkammer banned the use of indigenous languages in schools and emphasized the sole use of German as medium of instruction (Vischer, 1915, p. 136). ${ }^{22}$ Instruction in German was encouraged by financial grants-in-aid to mission schools. Catholic Pallottines started their mission in Marienberg, close to Edea. (Eyongetah and Brain, 1974, p. 7; Neba, 1987, p. 2). The head of the Pallottines missionaries in Cameroon around that time, Mgr Vieter, considered educating Cameroonians in German to the German way of life as a debt he owed his country. ${ }^{23}$ Basel Mission's language policy was to use local languages for instruction in school and evangelization in the church (Stumpf, 1979, pp. 28-30; Trudell, 2004). ${ }^{24}$ This policy was influenced by Johann Gottfried Herder and Gustav Warneck's theories about the fundamental value of language to the shaping of a people's culture and identity. ${ }^{25}$ In German Baptist schools, German and Duala were used. In 1900, a Protectorate Act (Schutzgebietgesetz) limited the use of local languages by missionaries to evangelization. According to Joseph (1980, p. 17), in 1910 a decree 'brought the church schools under closer state control and ordered that German had to be the dominant language of instruction' (see also Rudin,1938, p. 357; Wolf, 2001, p. 61). With the German administration's subsidies to mission schools, English was supplanted by German which became the predominant language of instruction. With time, education in the vernacular was interrupted and German became 'the only instructional language' (Kouega, 2008, p. 87; Vernon-Jackson, 1967, p. 12; Vischer, 1915, p. 136; Wolf, 2001, p. 59) ${ }^{26}$. Orosz (2008, p. 69-187) observes that the move to rein in religious denominations by the German and, as shall be discussed later, the French colonial administrations was patterned on anti-clerical laws known in Germany as Kulturkampf (1871) and in France as Associations Bill (1901) and enacted by German Chancellor Otto Von Bismarck and By Waldeck-Rousseau, one of the prime ministers of the Third Republic. These laws aimed at strengthening the authority of the state by reducing the influence of religious denominations and especially the Catholic Church and advocating the use of one language for instruction and evangelization. According to Orosz, the docile attitude of the Catholic Church in Cameroon towards following German and French colonial administrations' language policy regulations was redeeming and stemmed from the State-Church conflicts in Germany and France that led to the adoption of the above-mentioned anti-clerical laws. Orosz thus argues that in spite of their apparent differences in the late $19^{\text {th }}$ and early 20 centuries, the Germans and the French shared a number of core beliefs and values, including mutual suspicion of the Church and the value of language and education in forging a sense of national identity (Orosz, ibid., p. 9).

In 1914, Todd (1983, p. 162) documents the number of primary schools and pupils in the whole of the Kamerun Kolonie as follows: Basel Mission, 319 schools for 17,833 students; Roman Catholic Mission, 151 schools for 12,532 students; American Presbyterian Mission, 97 schools for 6,545 students; German Baptist Mission, 57 schools for 3,151 students; Colonial government, 5 schools for about 800 students. Todd's record contrasts with LeVine (1964, p. 72)'s which indicates that there were 64 government schools with 833 pupils in roll throughout the colony as opposed to 631 mission schools with 49,000 pupils (see also Wolf, 2001, p. 59). However, both accounts show the role of missionaries in 
education during the German administration as very significant. Their role in the standardization and use of some local languages in education and for evangelization was also considerable. ${ }^{27}$ With Germany's defeat in World War I, Cameroon became a League of Nations mandated territory.

\subsection{From Mandate (1922-1946) to Trusteeship (1946-1960/1961): British and French Cameroons ${ }^{28}$}

Cameroon was shared between France and Britain after their victory over Germany in World War I. The French share, referred to as French Cameroon, was around $432,000 \mathrm{~km}^{2}$ while the British possession was called British Cameroons and consisted of about 272,725 km² (Gardinier, 1967; Eyongetah and Brain, 1974, p. 97; Mahwood, 1993, p. 189). It was composed of two discontinuous strips of land along the Cameroon-Nigeria borders. The strip in the north was referred to as Northern Cameroon and the strip in the south was called Southern Cameroon, also known as the Cameroon Province (see Figure 3 below). ${ }^{29}$

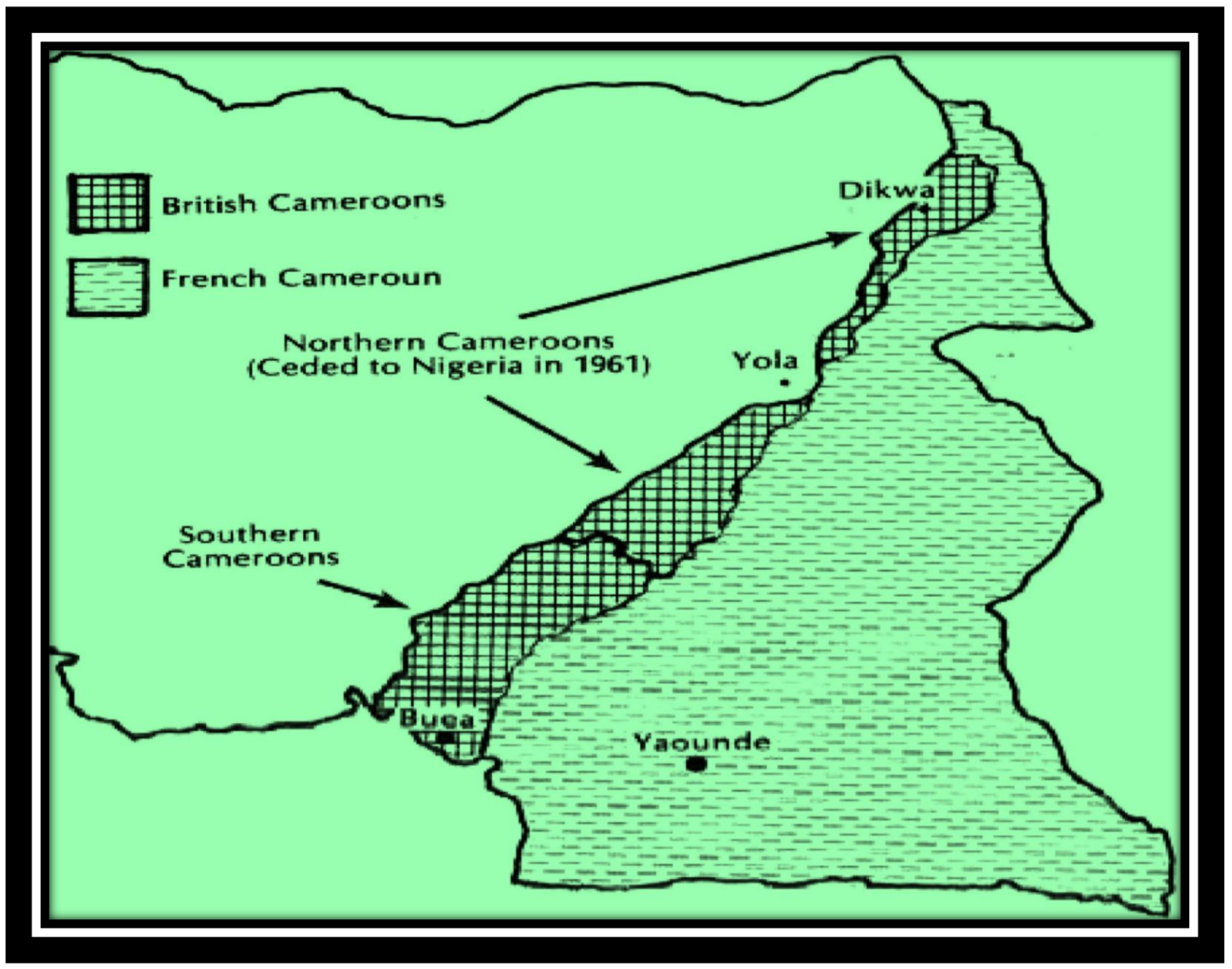

Figure:3. Cameroon Mandated Territories (1922-1946) and Trust Territories (1946-1961). Source: (Neba, 1987: 5).

The sharing of German Cameroon was given legal recognition through a treaty signed in Versailles in 1919. The League of Nations, created shortly after this, confirmed the de facto annexation of Cameroon by France and Britain and mandated them to run and develop their respective shares. The Covenant of the League of Nations in its article 22(1) talks of a civilization mission with reference to the administration of colonies, and even stipulates in article 22(6) that certain colonial possessions such as those in South Western Africa could be administered as an integral part of the colonial powers having mandate over them. The League of Nations mandate to Britain and France ran from 1922 to 1946 when the Second World War ended. After the war, the United Nations Organization replaced the League of Nations. As a result, the Cameroon League of Nations mandated territories were renamed the UNO Trust Territories (see Figure 3 above). This change of appellation did not affect the administrative system already put in place, as the territories continued to be administered by their respective colonial masters until independence in the 1960s. 
Vernon-Jackson (1967, p. 13) observes that formal education declined in Cameroon after World War I. Schools, mostly run by missionaries, were closed down as German missionaries were forced to leave the country and German abruptly ceased to be the language of trade, administration and education. Military officers oversaw the few schools that remained operational with little zeal and there was much suspicion of some missionaries like Carl Bender, who was German born but held US citizenship and was allowed to stay thanks to his US nationality (Vernon-Jackson, 1968, pp. 361-364) ${ }^{30}$ The British, for instance, feared that 'old missionaries, who have served under German societies like the Basel and the German Baptist in the pre-war period, would see the mandate status as only temporary and therefore encourage Cameroonians to sympathize with a return of the colony to Germany' (Weber, 1993, p. 35). While the British fears could be justified by the fact that, like the Germans, they mostly relied on missionaries for education, the French had little or no such fears as Aymerich, the first military commander in French Cameroon, drafted an official school programme in 1916 which emphasized the use of French as the medium of instruction from the first year of primary education (Weber, ibid., p.35). ${ }^{31}$ The French were essentially concerned with eradicating three decades of German presence in Cameroon through the promotion of French in education, the administration and public life.

\subsubsection{Language and Education in British and French Cameroons}

\subsubsection{British Cameroons (1922-1961)}

\subsection{Background to the British Colonial and Educational Policy in Africa}

It has been suggested that differences in colonial policy were conditioned by local, socio-political and economic realities, the role of missionaries and 'the moral stances underlying colonial practice' (Reynaud-Paligot, 2006; Trudell, 2004, p. 84; White, 1996; Wolf, 2001, p. 82). The indirect rule policy underlying British colonial administration was perceived by some as a mixture of enlightened paternalism and traditional pragmatism (Whitehead, 1995, 1999; Hetherington, 1978). ${ }^{32}$

British education policy in Africa was based on adaptation or 'education for life' which consisted of training the Africans to fit within their place in the colonial machinery (Mwita Akira, 2007; Whitehead, 1999). ${ }^{33}$ This policy was inspired by The Privy Council Memorandum ${ }^{34}$ on industrial schools for coloured races, produced in 1847 by the committee of the Council on Education. ${ }^{35}$ In the 1920s, Thomas Jesse Jones drew on the experience of training African-Americans in the southern states of the US to advocate similar training for the Africans. ${ }^{36}$ Two Phelps-Stokes Commissions chaired by Jones then toured Africa between 1920 and 1924 and came up in their reports with recommendations about what was viewed as a beneficial form of education for the Africans. ${ }^{37}$ These recommendations saw no need for literary education for the Africans, advocated that education for the Africans, as for African-Americans, be tailored to address what was regarded as their 'backwardness' and should give priority to agricultural training (Ball, 1983; Bude, 1985, p. 74; Heyman et al., 1972, p. 97; King, 1971; Mwita Akira, 2007; Sinclair, 1976; Wilson, 1963). ${ }^{38}$ The reports also encouraged the use of African languages in education in order to avoid severing the Africans from their roots.

In June 1923, a conference held in London on 'the future of Native Education in Africa' ${ }^{39}$ The conference considered a memorandum ${ }^{40}$ entitled Education Policy in Africa, submitted earlier by the Education Committee of the Conference of Missionary Societies in Great Britain and Ireland. ${ }^{41}$ The conference decided that the results of education in Africa were unsatisfactory and this realization led to the formation of ACNETA. ${ }^{42}$ In March 1925, ACNETA submitted to the British government its first policy statement entitled Education Policy in British Tropical Africa. The document substantially drew on the two Phelps-Stokes Commissions' reports and advocated an education that was 'adapted to the mentality, aptitudes, occupations and traditions of various peoples' and whose aim was to 'render the individual more efficient in his or her own condition of life... through the improvement of agriculture, the development of native industries, [and] the improvement of health.... 43

On the question of language, a draft memorandum on the place of the vernacular in native education was up. It emphasized the use of the mother tongue as language of instruction in the early years of schooling. The vernacular was to be the medium of instruction in elementary as well as in secondary school with the exception of the highest classes where English was taught only to pupils who intended to pursue their studies at a higher level. ${ }^{44}$ The subjects English, mathematics and science were to be taught entirely in English. It is suggested that the committee's stance on the language of instruction in British African colonies differed from British language policy in nineteenth century India where schooling in English had been allowed to proliferate unchecked on the grounds that it was the necessary vehicle of 'useful knowledge' which was needed for the modernization of a morally and economically bankrupt society (Sirkin and Robinson, 1971; Whitehead, 1995, p. 4). Whitehead (2007, p. 6) points out that this led to the production of an intellectual proletariat or 'babu' class who only dreamt of white-collar employment in government departments and who viewed anything less than that as below their status. With the growth of the 'babu' class intellectual and the lack of white-collar employment for them, this class of intellectual became militants of the Indian nationalist movement 
advocating independence. According to Whitehead (2000), it was to avoid a replication of the Indian situation in Africa that the Advisory Committee laid emphasis on developing primary vernacular education and limiting the spread of English secondary education. ${ }^{45}$

The move to make African education espouse the needs of a rural lifestyle was perceived by the Africans as a wish by the colonial power to keep them 'in their place'. This perception was reinforced by the recommendation of the Advisory Committee to use the mother tongue as language of instruction in education in all British colonies in Africa. This was seen by the Africans as an attempt to prevent them from reaping the benefits of modern life which came through the knowledge of English and education in English. ${ }^{46}$ On the basis of views from education practitioners in various colonies, the Advisory Committee revised the draft memorandum which was approved for distribution to colonial governments in May 1927 by the Colonial Office. The revised memorandum acknowledged that the demand for English education was in excess of the supply and pointed out that the delay to introduce English into African schools could be regarded 'as an attempt of the Government to hold back the African from legitimate advance in civilization'. ${ }^{47}$ Increasingly, English occupied a significant place in education in British African colonies to the extent that the perception about its role as a vehicle of civilization appeared to be axiomatic. English was perceived as being:

Important to Africans for three main reasons; as a lingua franca; as a road to the technical knowledge of modern inventions; and a means of contact with world thought...The African needs English today in the same sense and to the same degree as the Renaissance European needed Greek or Greek thought in Latin form. English thought could come to Africa with all the liberating power of Greek thought to Europe. Language carries with it the spiritual values on which it is based (Ward, 1953, p. 82).

The above quotation has the resonance of Du Bellay's arguments in his La défense et illustration de la langue française with reference to the power of a language in carrying the culture that it transmits. In reality, in areas where the influence of the English language was threatened by the dominance of a local lingua franca, as in the case of Swahili in Kenya, the suggestion was that of 'a gradual elimination over the whole territory' (Ward, ibid., p. 82; British Government, 1929, p. 75).

Notwithstanding the shift towards the teaching of English in schools in British African colonies, mother tongue education was never abandoned and subsequent language policy development suggested bilingualism in English and the mother tongue as a way of resolving the language question. In 1929, Arthur Mayhew tabled a memorandum on the issue in which he highlighted the growing demand for knowledge of English in the colonies, and also underscored the prime importance of mother tongue education. ${ }^{48}$ A subcommittee chaired by Michael Sadler was constituted to examine Mayhew's memorandum in detail. The revised memorandum named A preliminary memorandum on the aims and methods of language teaching in the colonies was eventually circulated in 1930 to colonial governments and 'bodies with expert knowledge of the subject'. The memorandum included a questionnaire which sought to have maximum information on language policy in each of the colonies. Two reports from African and non-African territories were later compiled based on the answers to the questionnaire. Whitehead $(1995$, p. 13) suggests that the report from African colonies indicated that practice was mostly in line with the 1927 memorandum mentioned earlier. ${ }^{49}$ Both reports were approved by the Advisory Committee in 1931 and transmitted to the Colonial Secretary for circulation. However, Whitehead (ibid.) notes that there seems to be no evidence of such circulation as the Colonial Office mostly relied on a policy of expediency in the colonies which consisted in the 'exercise of a traditional skill in accommodating principles to circumstances' (Hailey, 1938, pp. 1260-69). Another memorandum on language teaching in African education was issued on the 27 November 1942 by H. S. Scott. ${ }^{50}$ Scott examined the language problem in African education through a longitudinal survey and aligned his conclusions with those of the 1927 memorandum on the place of the vernacular in native education. Whitehead (1995, p. 14) observes that, as pragmatic as British language policy may have been, there was no dramatic shift in emphasis after the colonies gained independence. In West Cameroon, mother tongue education was discarded as English assumed the sole status of medium of instruction in schools.

\subsection{British Colonial Policy in Cameroon}

Indirect rule in British Cameroons consisted of giving some latitude to local traditional authorities regarding the performance of most executive and judicial functions (Nkwi and Warnier, 1982, p. 217). ${ }^{51}$ Rubin (1971, p. 74) remarks that this system ${ }^{52}$ was deemed appealing to the British colonial administration because of its perceived respect for local traditions and its economy on manpower and money. Unlike the German administration, the British abolished forced labour and labour tax and amalgamated plantations seized from German farmers into the Cameroon Development Corporation ${ }^{53}$ where workers were paid wages (Davidson, 1944, p. 3; LeVine, 1964, p. 196; O'Kelly, 1950; Sivonen, 1995, p. 17; Wise, 1959). ${ }^{54}$ Indirect rule was more successful in Northern Cameroon, where the British relied on long-established Fulani emirates, than in Southern Cameroon where some areas lacked a centralized traditional authority and the British administration had to appoint headmen to help them administer the population (Chiabi, 1997, 
pp.18-19). This contextualized approach in dealing with situations characterized an aspect of the indirect rule policy which 'sought broad agreement in thought between officials in Whitehall and those at the periphery of the empire' (Whitehead, 1995, 11). In keeping with the indirect rule policy, British administration's language policy was that of tolerance towards the use of local languages in education, although English-medium education eventually became dominant, reinforced by its use in government (British Government, 1934, p. 77; Robinson, 1996, p. 116).

\subsection{Language and Education in British Cameroons}

Education and language policy at the start of British mandate was lackadaisical ${ }^{55}$ and different in the two British Cameroons (Fonlon, 1969, p. 36). ${ }^{56}$ The school system was almost non-existent with a language policy limited to the use of English by government officials arriving from Nigeria (Vernon-Jackson, 1967, p. 18; Wolf, 2001, p. 82). This period has been referred to as the 'the dark years' for education in Anglophone Cameroon (Shu, 1982). Vernon-Jackson (1967, pp. 16-17) asserts that by the mid-1920s there were only primary Koranic schools with no mission or government schools in Northern Cameroon. Eventually, Gardinier (1967) points out that schools established in Northern Cameroon were part of the educational system of the northern provinces of Nigeria and government education officers from Nigerian viewed the Cameroon territories as no more than districts of Nigerian provinces. Schools in British Cameroons followed the Nigerian system of education, which, according to DeLancey and DeLancey (2000, p. 30), was a facsimile of the system in Britain. Local languages were used in elementary schools, followed in higher classes by instruction in English. ${ }^{57}$ This was in line with a 1934 Report to the League of Nations which stipulated that 'the medium of instruction is an African language where there is one of sufficient importance to become a lingua franca. Elsewhere, English is taught in the elementary schools and becomes the language of instruction by the end of the course' (British Government, 1934, pp. 77-78; Baker and Prys Jones, 1998, p. 356). ${ }^{58}$ The same Report indicates that by 1934 there were no middle schools in British Cameroons, although some middle school classes were appended to elementary schools in view of enabling promising pupils to continue with their studies in full middle schools in adjacent provinces of Nigeria. ${ }^{59}$ The language of these middle school classes was English. Elementary school lasted from 4 to 6 years while middle school lasted 6 years. For further training at secondary, teacher training, and technical institutions, students went to Nigeria where English was the official language (Vernon-Jackson, 1967). ${ }^{60}$

Southern Cameroon was educationally linked to the eastern region of Nigeria with an almost non-existent educational policy. ${ }^{61}$ Both Northern and Southern Cameroons were described as rural areas and as such had only elementary schools with a dominant vernacular curriculum. Four types of schools existed in Cameroon Province by 1922: Government-administrated schools; Native Administration schools (run by local Cameroonian authorities); mission schools, under Catholic and Protestant missions; and 'hedge' or 'unofficial native schools', also referred to as vernacular schools or bush schools (British Government, 1922, p. 42). Created by the Basel Mission before World War I, vernacular schools mushroomed rapidly throughout the country and numbered 114 by 1925 with an enrolment of 3,207 pupils. Basel Mission maintained its focus on using local languages in its schools, mostly Duala and Mungaka. The British Catholic Mill Hill Fathers, who replaced the German Pallottine order in 1922, had no fixed language policy and used English and Pidgin English in their schools while Pidgin English and local languages were used in catechumenates. $^{62}$ The Baptist ${ }^{63}$ Mission used English, Pidgin or Duala in its schools and churches. Native Administration schools were established to serve particular communities and used the language spoken by each of these communities (British Government, 1927, p. 61). ${ }^{64}$ Government schools used English and Duala in four of their six schools. ${ }^{65}$ In a report to the Council of the League of Nations in 1928 the British colonial administration noted that 'it has been found impossible to use only the vernacular and it has been necessary to introduce English at the very beginning' (British Government, 1928, p. 77).

With the Nigerian Education Ordinance for the regulation of schools of 1926, a government education officer was appointed to Southern Cameroon. Around this period, there were six government schools in Southern Cameroon, ten Native Administration, six Catholic and 130 Basel Mission vernacular schools ${ }^{66}$ which were threatened with closure (British Government, 1923, p. 52, 1926, p. 75). The schools were described as unauthorized by the government, unregistered, uncontrolled and mostly using untrained teachers. ${ }^{67}$ The Education Ordinance introduced methods to be used in all branches of education, highlighted the qualifications necessary for teachers and regulated the opening and closing of schools as well as the administration of grants-in-aid to non-government schools (British Government, 1927, p. 55; Booth, 1995, p. 72). Basel Mission vernacular schools were thus deemed below standard as their teachers were subject to no requirements regarding training, standards of English or curriculum content. Keller (1969, p. 65) mentions that the schools were eventually reduced to the status of 'religious schools ${ }^{68}$ in which reading, writing and religious instruction in the vernacular were permitted. While the colonial government argued that the problem with vernacular schools was not their use of local languages ${ }^{69}$, it appears paradoxical that vernacular schools' teachers were refused official recognition when they applied for it on the grounds that they did not speak English which was the language of the examination (Stumpf, 1979, p. 116). Ultimately, the Education Ordinance was modified and vernacular schools' 
teachers were allowed to apply for official recognition. ${ }^{70}$ The 393 teachers who applied for registration in 1928 and 1929 were asked to promise to 'only teach in schools where the instruction given is solely in the vernacular' (British Government, 1929, p. 75). This restriction was motivated by the desire 'to safeguard the purity and accuracy of the English taught'. In spite of the frictions between colonial education authorities and vernacular schools, the latter continued to gain prominence and education authorities had no other option but to appoint education supervisors to oversee their work and help them improve in quality (British Government, 1937, pp. 78-79). However, Basel Mission tribulations with colonial education authorities led to the creation by the mission in 1929 of three English primary schools in Buea, Besongabang and Bali. In 1931 another one was opened in Nyasoso. It is suggested that as the number of English schools increased, that of the vernacular schools decreased. ${ }^{71}$ The mission also undertook to develop the skills of its teachers by opening a Preliminary Teacher Training Centre in Nyasoso in 1944 where teachers were trained for a year, and in 1946 opened a Teacher Training Centre in Bali which was transferred to Batibo in $1947 .{ }^{72}$

Despite policy tolerance towards the use of local languages in schools, the language question came to bear on the distribution of grants-in-aid to schools and on the education choice of Cameroonians. Schools vying for 'quality education' increasingly sidelined Pidgin English and local languages. They were encouraged in this by the colonial government which kept trying to improve the standard of English as opposed to other languages (British Government, 1936, p. 93). Trudell (2004, p. 87), however claims that the lack of availability of English medium schools increased the popularity of vernacular schools. ${ }^{73}$ In its 1938 report to the League of Nations, the colonial government indicated that only 11 per cent of the 100,000 children of school age in British Cameroons received any form of education, either in English or the vernacular, and blamed this low school attendance on the lack of communication in sparsely populated rural districts and the reluctance of farmers to release their children for education. The report viewed the prospect of proximity education in terms of an increase of small schools and corresponding expansion of teaching staff and inspectorate (British Government, 1938, p. 81).

Stumpf (1979, p. 124) describes the 1940s as 'the most dynamic period' for the improvement of primary education in the Cameroon Province. The war years also revived anti-German sentiments which led, again, to the expulsion of German missionaries, traders and plantation owners who regained business in the late 1920s (Ndi, 1986). ${ }^{74}$ Ndi upholds that in June 1940, the British interned all the Germans on the plantations and did the same for all male "enemy alien missionaries' who were suspected of collaboration with the Axis powers. There were about 50 such missionaries in the province (German and Italians) of trusted character and supported by powerful international mission organizations. Ndi indicates that all but four of the Swiss and German Basel missionaries had to leave, and all but three of the German-American Baptist missionaries, while the Mill Hill Mission, composed mainly of English, Irish and Dutch personnel, only lost seven of its around 30 missionaries. ${ }^{75}$ Stumpf's description of the 1940s as the most fruitful years of primary education development in Southern Cameroon could also be understood in relation to the Colonial Welfare and Development Act of 1940 and the Education Act of 1944 which boosted the British government's commitment to education in the colonies. Missionaries started receiving financial aid from the government which insisted on the introduction of English to replace the vernacular in the second year of primary school (Vernon-Jackson, 1967, pp. 16-17). Trudell (2004, p. 88) indicates that religious education was introduced in every school and translated government's concern over the influences of the 'Nazi peril' and communism.

English medium education gained prominence around this period with the various religious denominations, except the Basel Mission, opting for English as the only medium of instruction. ${ }^{76}$ However, the Basel Mission's long-lasting battle for vernacular education was coming to an end. The mission's policy of using only Duala and Mungaka as languages of instruction became problematic as other ethnicities opposed the use of these languages in schools in their localities (Trudell, ibid., p. 82; Thomas, 2001, p. 167). ${ }^{77}$ Stumpf $(1979$, p. 126) mentions that the Duala language also became suspicious in the eyes of British Colonial authorities during the war years as it was used in the dissemination of seditious German propaganda. Eventually, Wolf (2001, p. 91) notes, at the end of the war, the government reported to the League of Nations that the use of Duala and Mungaka did not actually meet the language needs of the Cameroonian people and advocated the use of English instead. The use of Mungaka for teaching was confined to the Bali area in 1954 by the provincial education officer, while in 1956 the provincial Board of Education decreed that the vernacular could be used as a medium of instruction only in places where at least two thirds of the children spoke it as a first language. In 1958, the autonomous government of Southern Cameroon decided that: 'although the mother tongue of children may be used to assist in introduction, English is to be the medium of instruction in Primary Schools and all the text books are to be in English' (Keller, 1969, p. 73). This ruling ended Basel Mission's policy of vernacular education even though local languages could still be used for religious instruction. However, as mentioned earlier, the mission had already given in to English medium of instruction advocacy as its stance was shifted in 1929 when it opened English medium primary schools (Wolf, 2001, p. 88; Thomas, 2001, p. 167) ${ }^{78}$ In 1949 it also opened a secondary school ${ }^{79}$ in Bali and from 1958 fully turned its attention to English-medium education (Ndi, 1986, p. 223). 
While the British language in education policy in Africa appeared to be mindful of the sociocultural and cognitive development of the child and, by so doing, preceding and aligning itself with an assertion of a UNESCO committee on The Use of Vernacular Languages in Education, the introduction of mother tongue as language of instruction in the early years of primary education only had to serve an awakening purpose and the language was subsequently replaced by English (Ward, 1953; UNESCO, 1953). Nonetheless, Trudell (2004, p. 84) points out that the African's ambition to explore European thought in English beyond primary education in British Cameroons appeared to have been curbed by what is referred to as the neglect of British colonial philosophy of indirect rule concerning education. It is argued that the British colonial administration was not interested in the long-term educational development of the Cameroons as 'Government was not viewing educational development in terms of African [Cameroonian] political development, since education was designed merely to serve the needs of the administration while helping to improve rural living conditions' (Booth, 1995, p. 73; Bude, 1985, p. 40; Roger, 1967; Trudell, 2004, pp. 80-83; Whitehead, 2000; Wolf, 2001, p. 82) ${ }^{80}$ Education was thus limited to the primary level. Secondary and tertiary level education was only offered in Nigeria (Che, 2008; Ihims, 2003; Tchombe, 2001, p. 9; Wolf, 2001, p. 84). ${ }^{81}$ Eventually, in 1937, the Mill Hill Mission established the first secondary school, St Joseph College Sasse, in Bonjongo, Buea.

Language policy in education in British Cameroons differed from that in application during the German era when German was promoted as the only language of instruction in schools. The policy of exclusive use of German in education parallels that in application in schools in French Cameroon with regard to the use of French. British language policy was influenced by the fact that education was mostly in the hands of missionaries who used local languages for evangelization and instruction (Johnson, 1970, p. 84). ${ }^{82}$ Shaped by the Indian experience, policy statements at the start of British colonial administration in Africa advocated the use of the vernacular and laid emphasis on the education for life concept that sought to adapt schooling to the needs of a rural life style. In British Cameroons, this policy limited access to government secondary education. The first government secondary school was only created after reunification in 1961. The lack of a government secondary school in the whole of British Cameroon was also justified by the Nigerian colonial administration's categorization of the region as a 'rural area' (Chiabi, 1997). ${ }^{83}$ By this virtue, Northern and Southern Cameroons could only extend their primary education to a secondary level if there was a change in the designation of the localities as rural (Wolf, 2001, p. 87). However, and as mentioned earlier (Whitehead, 2000), critics indicate that the reluctance to provide secondary education across British African colonies reflected the British government's general policy of limiting access to this level of education (British Colonial Office, 1927, p. 18; Gifford and Weiskel, 1971). British colonial administration's education and language policies in Cameroon were in stark contrast to those of the French administration which, in keeping with republican ideals, perceived education as being of the masses and the use of French as medium of instruction as an underlying factor in the inculcation of such ideals.

\subsection{French Cameroon (1922-1960)}

\subsection{Background to the French Colonial and Educational Policy in Africa}

As the official language of the French Republic, French is perceived as an essential attribute in the shaping of a national character in France and the ascription of French identity. This perception governed France's colonial policy with regard to educating people in her colonies to aspire to French citizenship and pledging allegiance to France. Also, the constitution of the Fourth Republic adopted in 1946 stipulated in its part VIII, sections 1, 2 and 3, articles 60-82 that French colonies were French territories and were to be administered as part of France (Mbala Owono, 1986, p. 51). ${ }^{84}$ The insertion of articles 60-82 in the constitution followed a conference held in Brazzaville in 1944 on the role and future of the French empire and during which an assimilationist policy in favour of the colonies was adopted. ${ }^{85}$ As a consequence, the education system in French colonies was modelled on that of France.

Calvet (1979, p. 57) argues that colonizers' languages played an essential role in the consolidation of colonialism, as the right to name places and people was the linguistic side of the right to appropriate. This led to a harmonious dichotomous organization that comforted the imperialist nations as concepts such as savage/civilized, language/dialect, people/tribe and many others were antagonized with the avowed aim of furthering colonialist ideologies (see also Goody, 1977). The pivotal role played by the colonizers' languages in the success of colonialism and mostly the alienation of the colonized through the use of those languages as media of education is described by Hardy in the following quote with regard to French:

En admettant même, dit le Plan d'Etudes de 1914, que l'enfant, rendu à la vie familiale, perde l'usage de la langue française, on ne prétendra pas qu'il puisse effacer de sa mémoire les notions bienfaisantes que, par l'intermédiaire de cette langue, on aura fait pénétrer en lui: les mots passeront peut-être, les idées resteront, et ces idées qui sont les nôtres, et dont l'usage constitue notre supériorité morale, sociale, économique, transformeront peu à peu les barbares d'hier en disciples et en auxiliaire (Hardy, 1917, p. 151). ${ }^{86}$

Thus, in French Cameroon, the colonial administration considered the teaching of French in schools as 'la porte ouverte 
vers la culture, vers l'avenir, vers le progrès' (Fonlon, 1969, p. 36) ${ }^{87}$ Fonlon (ibid.) mentions that there was a definite policy against encouraging African languages and the teaching of French was linked to the aim of assimilation of the natives to the French way of life and Quist (2001, p. 298) upholds that the French saw 'assimilation of the Africans as a definite moral obligation and this accounted for French colonial administration and education in most of the African colonies under French rule'.

\subsection{French Colonial Policy in Cameroon}

In French Cameroon, unlike with the Germans and the British, the French administration did not rely heavily on the services of local chiefs to assist it in administering the territory under its rule. The authority of chiefs was reduced to a mere auxiliary of the administration and they could be hired and fired at will (LeVine, 1964, pp. 92-98; Rubin, 1971, pp. 49-50). Based on the principle of assimilation, the French administration integrated Cameroonians évolués with western education in its system (Lee and Schultz, 2012, p. 11). ${ }^{88}$ The évolués, who were granted French citizenship and the accompanying legal rights, could seek elections to urban councils and the French parliament. The majority of unassimilated population remained under la loi de l'indigénat which was chiefly unpopular because it authorized forced labour (Rubin, 1938, p. 57) ${ }^{89}$ Forced labour was initiated by the Germans but banned by the British. LeVine (1964, pp. 104-110) indicates that forced labour was renamed prestation by the French who used unpaid and badly treated workers for railway construction. ${ }^{90}$

\subsection{Language and Education in French Cameroon}

In education, the mission school was supported 'only in so far as it provided instruction in the French language and developed sentiments of loyalty to France' (see also the 1901 Associations Bill mentioned earlier in relation to the application of anti-clerical laws to missionary bodies in France). The first French commander to Cameroon, General Aymerich, who assumed office in March 1916, issued a circular on the 29 August 1916 fixing school programmes and giving priority to the teaching of French. On the 24 January 1918, he signed a decree instituting official education. Unlike in British Cameroons where education was mostly in the hands of missionaries and where the British, at the start of their administration, did not really have to make a tremendous effort for the spread of English, the French, like the Germans in their time, at the beginning of their rule in Cameroon had to set up an administrative and educational system that reflected their colonial policy and especially favoured the use of French to counter the influence of German. ${ }^{91}$ Given the secular option of the French state, the French administration was faced with a dilemma in Cameroon where missionaries had already started schools long before its inception. It thus became necessary to institute, like during the French Third Republic with the introduction of Ferry's secular education system, an official education programme to regulate mission schools and subsidize schools that exclusively used French as medium of instruction. On the 1 October 1920, Jules Cadre, the first French commissioner to Cameroon, issued a decree which in its article 2 conditioned the existence of private schools to their acceptance of French as the sole medium of instruction (Mbala Owono, 1986, pp.54-77). In article 46 of another decree relating to official education issued again by Cadre on the 25 July 1921, it is stipulated that:

Aucun livre ni brochure, aucun imprimé ni manuscrit étrangers à l'enseignement ne peuvent être introduits à

l'école sans autorisation du Commissaire de la République. La langue française est seule en usage dans les écoles.

Il est interdit aux maitres de se servir avec leurs élèves des idiomes du pays (Atangana, 1996, p. 436). ${ }^{92}$

The ruling about the exclusive ${ }^{93}$ use of French in schools remained in force up to 1945 when the education system in the colonies was modelled on that of France (Mbala Owono, 1986, pp. 26-30). Retrospectively, Cadre's decree was a tropical facsimile of the one taken by Jules Ferry on the 7 June 1880 in France where in article 14 it was stipulated that: 'Le français sera seul en usage dans les écoles' and in article 16 it was stressed that: 'Aucun livre ni brochure, aucun imprimé ni manuscrit étrangers à l'enseignement ne peuvent être introduits dans l'école sans l'autorisation écrite de l'inspecteur d'académie' (Girardin and Laguerre, 1836-1952).

A hallowed principle of the League of Nations Mandate system, however, encouraged the use of the vernacular in the first few years of schooling in the dependencies (UNESCO, 1953, p. 11). According to Joseph, 'this policy was based on the wish to avoid wrenching Africans too brutally away from their cultures and traditions, as well as on solid pedagogical grounds: the greater advance that could allegedly be made in the individual's education if schooling was initiated in the language of the mother' (Joseph, 1980, pp 19-20). Nevertheless, Joseph notes that 'despite the repeated up-braiding of French delegates on this issue by members of the Permanent Mandates Commission, the French continued to give priority to the total and early ideological conditioning of the African over liberal sentiments about preserving African culture and fears about creating uprooted black Frenchmen' (Joseph, ibid.; Buell, 1928).

Echu (1999) indicates that there existed perpetual conflict between missionaries who persisted in the use of indigenous languages and the French administration. The latter took a series of measures in the 1920s aimed at promoting French while relegating indigenous languages to the periphery. In 1917 a special subvention was instituted for schools which 
used French as the language of instruction. Eventually, schools that taught in indigenous languages were suppressed. Djité (1990) points out that the decree of 1920 conditioning the existence of private education to the sole use of French as medium of instruction was in force in the whole of Afrique Equatoriale Française of which Cameroon was administratively a part. According to Robinson, the reasons justifying the decree were: 'too many languages, so too much disunity in the territory; local languages are incapable of expressing abstract ideas; unity of language reinforces unity between colony and mother country' (Robinson, 1996, p.115).

In the wake of the 1920 decree, a debate ensued in the 'Métropole' regarding the extent to which French or Cameroonian languages could be used in schools (Atangana, 1996; Hardy, 1917, p. 148; Mbala Owono, 1986, p. 77). Views were divided between those who felt that a neglect of local languages would lead to 'fonctionnarisme' to the detriment of agriculture and those who upheld that banning local languages in school was in line with the French colonial administration's civilization mission which could only be achieved through the use of French and the mastery of the latter by the colonized. Hardy's view clearly illustrated this position. He understood the mission of French colonization as:

transformer les peuples primitifs de nos colonies, pour les rendre le plus possible dévoués à notre cause et utiles à nos entreprises, nous n'avons à notre disposition qu'un nombre très limité de moyens, et le moyen le plus sûr, c'est de prendre l'indigène dès l'enfance, d'obtenir de lui qu'il nous fréquente assidûment et qu'il subisse nos habitudes intellectuelles et morales pendant plusieurs années de suite; en un mot, de lui ouvrir des écoles où son esprit se forme à nos intentions. (Hardy, 1917, p. 6)94

The $1^{\text {st }}$ of October and 28 December 1920 decisions taken by the French administration against the teaching of local languages in schools prompted the closing down of 47 schools, opened by King Njoya in the Bamun area, which used Shumum as language of instruction. As from 1922, 1,800 schools run by the American Presbyterians which used Bulu suffered the same fate. This systematic linguistic persecution was carried out with vigour until French became the only language of instruction (Echu, 1999; Stumpf, 1979). ${ }^{95}$ In the last decade of the trusteeship, scholarships were instituted that favoured further studies in France and the creation of a French-minded class of évolués (Djité, 1990; Fonlon, 1969, p. 37). ${ }^{96}$

It could be argued that people in French Cameroon were conditioned, through the use of French, to the French way of life and that such conditioning presumably accounted for the choice of French as official language when this part of Cameroun became independent (see also Ihims, 2003). ${ }^{97}$ The option for English as official language in Southern Cameroon appears not to respond to the same principle, given the British colonial policy of indirect rule. However, Stumpf points out that the pre-independence West Cameroon Department of Education in 1958 reinforced the use of English in education and Todd notes that by 1959 English has supplanted vernacular education and 99 per cent of children in schools were taught through the medium of English (Robinson, 1996, p. 116; Stumpf, 1979, p. 60; Todd, 1983, p. 167). ${ }^{98}$

The likelihood of English and French as post-independence official languages was very apparent; given the sustained exclusion of local languages from education and the public sphere in French Cameroon and the angelico-paternalistic British colonial administration's approach to language policy which seemingly tolerated the use of local languages in education and for evangelisation but would stealthily write to the League of Nations to advise against the use of Duala and Mungaka, two languages which enjoyed relative educational and evangelistic popularity. While colonizers' ideologies in most cases aimed at modernising indigeneity by bringing 'civilisation' to the locals via the use of their language, education and the church, conversely, there was a conscious move by the natives to indigenise modernity. An illustration of this are the efforts made by pastor Adolf Lotin A Same (the first Cameroonian to be ordained pastor by the German Baptist Mission in 1908) to give a local colouration to the Baptist Church in Cameroon. The chapel where he was a minister in Douala was named Native Baptist Church. His move to inculturate the church was made with stiff resistance by church leaders and French colonial powers (Ball et al., 2006, p. 49; DeLancey et al., 2010, p. 273). Lotin A Same's initiative and other instances of local determination exemplified in this study but suppressed by hegemonic colonial powers are examples of subaltern voices which were in dissonance with the cultural hegemonic rhythm Gramsci (1971) trumpeted by the colonial order. Unfortunately, in the entextualization of these 'stories told from below' (which are oftentimes not always written by those concerned), the strength of these 'heretic' voices could be made flat or distuned as the narrative lens might yet be ideologically focused.

\section{Language and Education in Present-day Cameroon}

Former French Cameroon became independent on the 1 January 1960 under the name of la République du Cameroun. The Southern Cameroon people chose union with la République du Cameroun by plebiscite on the 11 February 1961. On the 1 October 1961, both entities formed a Federation and adopted English and French as official languages. The Federal Republic of Cameroon became the United Republic of Cameroon by means of a referendum in 1972 and then 
the Republic of Cameroon in 1984 by means of a Presidential decree.

In Cameroon, the interweaving of the politics of language and ideology relates to the very existence of the state and raises the issue of the Cameroonian people as a nation. If a nation were to be defined by the language that her people speak, as is upheld by advocates of the 'one nation, one language' model, it might be said that Cameroon is not a nation or that it is many nations in one state, given that, in addition to English and French, Cameroon has a wealth of national languages. ${ }^{99}$ The rhetoric of English and French as international languages and as the only languages appropriate for education as championed by Fonlon ${ }^{100}$ prevailed when Cameroon became independent and had to consider the language issue for the sake of nation building (Fishman, 1968). Fonlon viewed no other option for Cameroon in the planning of the country's language policy and propounded official bilingualism as the best language model for education. He presumed that this would guarantee the country's economic stability, foster integration and national unity and link Cameroon to the rest of the world (Essono, 1981; Tadadjeu, 1990, p. 19). ${ }^{101}$

Reasons accounting for this choice appeared to be similar to those justifying the enactment of the 1920 colonial law regarding the use of local languages in schools outlined earlier. French was thought of as a 'no man's language', its adoption was less likely to spark language conflict and its perceived 'utilitarian' value as a global language and as a language of opportunities was also decisive in its choice (Echu, 1999, p. 22; Fishman, 1969; Fonlon, 1969, p. 36; Tangwa, 1999). Similar views were also held in West Cameroon regarding the adoption of English (Robinson, 1996). English and French are thus the official languages of Cameroon since 1961 and recognised as such in the country's constitution of 1 September 1961 and amended constitutions of 1972 and 1996. An official bilingualism policy has been implemented since the early 1960s and the education system is made up of two subsystems: Anglophone and Francophone. The 250-plus Cameroonian languages were sidelined in the planning of the country's language policy, despite the fact that some linguists working to codify Cameroonian languages for the purpose of schooling suggested different models (Bot Ba Njok, 1966; Ngijol, 1964; Tabi Manga, 2000; Tadadjeu, 1975; Todd, 1983). Tadadjeu for instance proposed a trilingual model; a national language, chosen from the 250-plus languages, in addition to English and French.

While during the colonial era ideologies about language applied differently in the territories under British and French rules, they appear to be in antagonism with the creation of the Cameroonian state and the adoption of English and French as official languages. Studies report on a language ideological divide grounded in historical and cultural claims related to the British and French colonial legacies in Cameroon (Fanso, 1999; Konings and Nyammnjoh, 2000; Nana, 2013a, 2013b; Nkwi, 2004, 2007). Beyond linguistic and cultural claims associated with the use of English and French, Nkwi contends that the apparent divide between Anglophones and Francophones in present-day Cameroon should be traced back to the colonial territories administered by the British and the French, while Awasom (2004) goes beyond the linguistic nature of the divide to perceive it as geographical and sociopolitical in nature. Anglophone identity claim grounded in linguistic and territorial legacy is still very rife today to the extent of fuelling separatist ideologies (Wolf, 1997; Toh, 2001). Linguistic and territorial division in Cameroon and beyond has also been entertained for underlying political motives by organisations such as la Francophonie and the commonwealth (Djité, 1990; Renou, 2002). ${ }^{102}$ Nonetheless, in Cameroon, Anglophones remain realistic about the necessity of becoming fluent in French to easily relate to fellow Francophone countrymen in an environment where French is used in eight out of the ten regions of the country (Chumbow and Simo Bobda, 1996).

In spite of advances ${ }^{103}$ in legislation in terms of acknowledging the existence of Cameroonian languages and introducing them in school ${ }^{104}$, English and French still hold sway in Cameroon schools (Phillipson, 1996; Twahirwa, 1994, p. 102). ${ }^{105}$ Development in legislation promoting the use of local languages in education seemingly indicates that the current language in education policy departs from a long tradition where schools were perceived as ideological institutions for the reproduction of the languages and cultures of the former colonial masters while local languages and cultures were not recognized (Bourdieu and Passeron, 1977). However, the fact that a law passed 17 years ago and promulgated by the head of state is still to be fully implemented may give credit to Kazadi quoted by Robinson who argues that 'aside from their virtues, constantly acclaimed in speeches, national languages [African languages - CR] have never been considered locally... as sufficiently serious to be given a budget, any planning or adequate institutions' (Robinson, 1996, p. 18). This situation has given rise to indigenous language awareness across communities in Cameroon and researchers like Chiatoh (2014) propound a community response framework in the absence of an adequate language policy addressing indigenous language promotion needs. According to Nyamjoh, the derision of African languages and values in schools is due to the fact that 'education in Africa is victim of a resilient colonial and colonising epistemology, which takes the form of science as ideology and hegemony' (Nyamjoh, 2012, p. 129). ${ }^{106}$ Nyamjoh argues that:

Postcolonial African elite justify the resilience of this epistemology and the education it inspires with rhetoric on the need to be competitive internationally. The outcome is often a devaluation of African creativity, agency and 
value systems, and an internalized sense of inadequacy. Education has become a compulsion for Africans to 'lighten their darkness' both physically and metaphorically in the interest of and for the gratification of colonising and hegemonic others (Nyamjoh, ibid., p. 129).

\section{Conclusions}

Cameroon as a multilingual country has a language in education policy that, until now, recognises English and French as official languages. The adoption of English and French as official languages stemmed from Cameroon's colonial past, when the country was partitioned and administered under mandate and trusteeship by Britain and France after World War I and the defeat of Germany which had Cameroon as a protectorate. In pre-colonial Cameroon, the language landscape of the country did not prefigure any significant linguistic hegemony among the many local languages. However, with the development of trade along the Cameroon coast, English, Pidgin English and some local languages soon gained prominence as languages of trade, administration, education and evangelization. The promotion of local languages was mostly due to the work of missionaries who used them for evangelization as well as in education. With the establishment of colonial rule, linguistic ideologies, missionary alliance and agency blanketed the work of missionaries who either pledged allegiance to the new colonial order or left the country. Language played an important role in the consolidation of colonial authority and each imperial nation in Cameroon championed the use of its language in education and the administration. While such advocacy, in the case of Germany and France, led to the adoption of laws aimed at enforcing the use of German and French in schools, the British administration's language policy was more accommodating of local languages, even though towards the close of the British rule emphasis was laid on the use of English as the medium of instruction in schools. The approach to language use in education translated British indirect rule and French assimilationist colonial policies which were applied in moulding Cameroonians under both imperial orders. The emphasis on English as a medium of instruction in schools in the later years of the British rule in Cameroon and the assimilationist approach implemented in French Cameroon influenced Cameroon's political elite of both colonial extractions who advocated the adoption of English and French as official languages at independence, to the detriment of local languages. However, the reasons advanced for the choice of English and French as official languages rather downplayed the underlying language ideological assumption as such choice was justified by the imperative of national unity and the need to relate to the wider world. Nonetheless, research suggests that national unity is still a far-fetched ideal while globalization is a composite of multiple localizations. It thus becomes essential to reconceptualise language policy and especially the medium of instruction policy as encompassing the teaching of Cameroonian languages in schools than submitting to a desquamating and unrequited colonizing epistemology as encapsulated in Nyamjoh's quote above. Moreover, in the UK and in France, language in education policy has long been that of unity in diversity and revitalization of minority languages (Baker and Prys Jones, 1998; Costa and Lambert, 2009, p. 8; Davies, 1999; Reynolds et al., 1998). ${ }^{107}$

\section{References}

ACNETA. (1925). Education Policy in British Tropical Africa. London: H. M. Stationery Office. http://www.historicalpapers.wits.ac.za/inventories/inv_pdfo/AD1715/AD1715-19-27-001-jpeg.pdf

Ager, D. (2001). Motivation in language planning and language policy. Clevedon: Multilingual Matters.

Ardener, E., \& Ardener, S. (1996). Kingdom on Mount Cameroon: Studies in History of the Cameroon Coast, 1500-1970. Oxford: Berghahn Books.

Atangana, E. (1996). Cent ans d'éducation scolaire au Cameroun : Réflexion sur la nature, les moyens et les objectifs de l'entreprise (1885 à nos jours). Paris: Harmattan.

Atayo, A. J. (2000). Cameroon Educational System. Buea: Loving World.

Awasom, N. F. (2004). Language and citizenship in Anglophone Cameroon. Paper given at the Centre of African Studies Annual International Conference, 19-20 May. University of Edinburgh.

Baker, C., \& Prys, J. S. (1998). Encyclopaedia of Bilingualism and Bilingual Education. Clevedon: Multilingual Matters.

Ball, S. J. (1983). Imperialism, social control and the colonial curriculum in Africa. Journal of Curriculum Studies, 15(3), 237-263. http://dx.doi.org/10.1080/0022027830150302

Ball, T., Blum, E. A., Rice, K., Kao, C. C., \& Hill, R. A. (2006). The Marcus Garvey and Universal Negro Improvement Association Papers, Vol. X: Africa for the Africans, 1923-1945. California: University of California Press.

Bamgbose, A. (1991). Language and the Nation: The Language Question in Sub-Saharan Africa. Edinburgh: Edinburgh University Press.

Berlin, I. (1976). Vico and Herder: Two Studies in the History of Ideas. London: Hogarth Press. 
Bitja'a Kody, Z. D. (2003). Annuaire des langues du Cameroun. Yaoundé: Cerdotola.

Boehmer, E. (2005). Colonial and Postcolonial Literature: Migrant Metaphors, $2^{\text {nd }}$ edition. Oxford: Oxford University Press.

Blommaert, J., \& Verschueren, J. (1998). The role of language in European nationalist ideologies. In B. B. Schieffelin, K. A. Woolard, and P. V. Kroskrity (Eds.), Language Ideologies: Practice and Theory (pp. 189-210). Oxford: Oxford University Press.

Booth, B. F. (1995). The Mill Hill fathers in West Cameroon: Educational development 1884-1970. Bethesda: International Scholars Publications.

Bot Ba Njok, H. M. (1966). Le problème linguistique au Cameroun. L'Afrique et l'Asie, 73, 3-13.

Bourdieu, P., \& Passeron, J. C. (1977). La Reproduction: Eléments pour une théorie du système d'enseignement. Paris: Minuit.

Breton, R. J. L., \& Bikia, F. G. (1991). Atlas administratif des langues nationales du Cameroun. Paris: ACCT.

British Colonial Office. (1927). British tropical Africa: The place of the vernacular in native education. Advisory Committee on Native Education in British Tropical Africa.

British Government. (1922). Report by the British Government to the Council of the League of Nations on the Administration of the British Cameroons. Oxford: Rhodes House Library 723.17 r.5.

British Government. (1923). Report by the British Government to the Council of the League of Nations on the Administration of the British Cameroons. Oxford: Rhodes House Library 723.17 r.5.

British Government. (1926). Report by the British Government to the Council of the League of Nations on the Administration of the British Cameroons. Oxford: Rhodes House Library 723.17 r.5.

British Government. (1927). Report by the British Government to the Council of the League of Nations on the Administration of the British Cameroons. Oxford: Rhodes House Library 723.17 r.5.

British Government. (1928). Report by the British Government to the Council of the League of Nations on the Administration of the British Cameroons. Oxford: Rhodes House Library 723.17 r.5.

British Government. (1929). Report by the British Government to the Council of the League of Nations on the Administration of the British Cameroons. Oxford: Rhodes House Library 723.17 r.5.

British Government. (1934) Report by the British Government to the Council of the League of Nations on the Administration of the British Cameroons. Oxford: Rhodes House Library 723.17 r.5.

British Government. (1936). Report by the British Government to the Council of the League of Nations on the Administration of the British Cameroons (Oxford: Rhodes House Library 723.17 r.5.

British Government. (1937). Report by the British Government to the Council of the League of Nations on the Administration of the British Cameroons. Oxford: Rhodes House Library 723.17 r.5.

British Government. (1938). Report by the British Government to the Council of the League of Nations on the Administration of the British Cameroons. Oxford: Rhodes House Library 723.17 r.5.

Bude, U. (1985). Primary Schools, Local Community and Development in Africa. Baden-Baden: Nomos Verlagsgesellchaft.

Buell, R. L. (1928). The Native Problem in Africa. New York: MacMillan.

Calvert, A. F. (1917). The Cameroons. London: T. Werner Laurie Ltd.

Calvet, L. J. (1979). Linguistique et colonialisme, petit traité de glottophagië, $2^{e}$ edition. Paris: Petite. Bibliothèque Payot.

Canny, N. (2003). Making Ireland British1580-1650. Oxford: OUP.

Carlton, J. H. H. (1928). Essays on Nationalism. New York: Macmillan.

Che, M. S. (2008). Domestic and international power relations in a Cameroonian mission school system. International Journal of Educational Development, 28, 640-655.

Chiabi, E. (1997). The Making of Modern Cameroon. Vol. 1. Lanham, MD: University Press of America.

Chiatoh, B. A. (2014). The Cameroonian experience in mother tongue education planning: the community response framework. Current Issues in Language Planning, 15(4), 376-392.

http://dx.doi.org/10.1080/14664208.2014.927087 
Chilver, E. M. (1967). Paramountcy and protection in the Cameroons: The Bali and the Germans, 1889-1913. In Prosser Gifford \& Wm. Roger Louis (Eds), Britain and Germany in Africa (479-511). New Haven and London: Yale University Press.

Chitty, C. (2007). Eugenics, Race and Intelligence in Education. London: Continuum.

Chumbow, S. B., \& Simo, B. A. (1996). The life-cycle of post-imperial English in Cameroon. J. A. Fishman, A. W. Conrad, \& A. Rubal-Lopez (Eds.), Post-Imperial English: Status Change in Former British and American Colonies 1940-1990 (pp. 401-429). Berlin: Mouton de Gruyter.

Conklin, A. L. (1997). A mission to civilize: The Republican Idea of Empire in France and in West Africa, $1895-1930$. Stanford: Stanford U.P.

Costa, J., \& Lambert, P. (2009). France and language(s): old policies and new challenges in education. Towards a renewed framework? Halshs-00439199, version 1(8). http://halshs.archives-ouvertes.fr/docs/00/43/91/99/PDF/CIDREE_final.pdf

Curtin, P. D. (1974). The Black Experience of Colonialism and Imperialism. Daedalus, 103(2), 17-29.

Davies, J. (1999). The Welsh language. Cardiff: University of Wales Press.

Davidson, R. A. (1944). Proposals for educational development in the Cameroons Province. Oxford: Rhodes House library MSS Afr. S.999.

Davies, J. (1999). The Welsh Language. Cardiff: University of Wales Press.

DeLancey, M. W., \& DeLancey, M. D. (2000). Historical dictionary of the Republic of Cameroon. Lanham, MD: Scarecrow Press.

DeLancey, M. D., Mbuh, R., \& DeLancey, M. W. (2010). Historical Dictionary of the Republic of Cameroon. Lanham, MD: Scarecrow Press.

Djité, P. G. (1990). Les langues africaines dans la nouvelle francophonie. Language Problems and Language Planning, 14(1), 20-32. http://dx.doi.org/10.1075/lplp.14.1.02dji

Eagleston, T. (1996). Literary Theory: An Introduction. Oxford: Wiley-Blackwell.

Echu, G. (1999). Colonialism and linguistic dilemmas in Africa: Cameroon as a paradigm (revisited). Quest XIII, 1-2, 19-26.

Echu, G. (2003). Coping with multilingualism: Trends in the evolution of language policy in Cameroon. PhiN, 25, 31-46. http://web.fu berlin.de/phin/phin25/p25t2.htm

Echu, G. (2004). The language question in Cameroon. Linguistik Online, 18(1). http://www.linguistik-online.de/18_04/echu.html

Erb, G. (1967). Les catholiques allemands. In M. Merle (Eds.), Les églises chrétiennes et la décolonisation (pp.249-280). Paris: Armand Colin.

Essono, J. M. (1981). De l'enseignement des langues nationales dans le secondaire: Les problems d'organisation. M. Tadadjeu (Eds.) L’Enseignement des Langues au Cameroun/Language Education in Cameroon (pp. 104-118). Yaoundé: University of Yaoundé.

Ethnologue. (2002). Languages of the World: Cameroon. http://www.ethnologue.com/show_country.asp?name=CM

Eyongetah, T., \& Brain, R. (1974). A history of the Cameroon. London: Longmans.

Falls, C. (1997). Elizabeth's Irish Wars. New York: Syracuse University Press.

Fanso, V. G. (1999). Anglophone and Francophone nationalisms in Cameroon. The Round Table, 350(1), $281-296$. http://dx.doi.org/10.1080/003585399108153

Fishman, J. A. (1968). Nationality-nationalism and nation-nationism. J. A. Fishman, C. A. Ferguson, and J. Dasgupta (Eds.), Language Problems of Developing Nations. New York: John Wiley and Sons.

Fishman, J. A. (1969). National languages and languages of wider communication in the developing nations. Anthropological Linguistics, 11(4), 111-135

Fishman, J. A. (1989). Language and Ethnicity in Minority Sociolinguistic Perspective. Clevedon: Multilingual Matters.

Fonlon, B. (1969). The language problem in Cameroon: A historical perspective. Comparative Education, 5(1), $25-49$. http://dx.doi.org/10.1080/0305006690050105

Fonyuy, K. E. (2010). The rush for English education in urban Cameroon: Sociolinguistic implications and prospects. 
English Today, 26(1), 34-42. http://dx.doi.org/10.1017/S0266078409990289

Gardinier, D. E. (1967). The British in the Cameroons, 1919-1939. In P. Gifford \& W. R. Louis (Eds.), Britain and Germany in Africa: Imperial Rivalry and Colonial Rule (513-555). New Haven: Yale University Press.

Gates, B. (2005). Faith schools and colleges of education since 1800. R. Gardner, D. Lawton, and J. Cairns (Eds), Faith Schools: Consensus or Conflict? (pp. 14-35). Abingdon: Routledge Falmer.

Gee, J. P. (1988). Discourse systems and aspirin bottles: On literacy. Journal of Education, 170(1), 27-40.

Gifford, P., \& Weiskel, T. C. (1971). African education in a colonial context: French and British styles. P. Gifford and W. R. Louis (Eds.), France and Britain in Africa: Imperial Rivalry and Colonial Rule (pp. 663-711). New Haven: Yale University.

Gillard, D. (2011). Education in England: a brief history. www.educationengland.org.uk/history.

Girardin, É., \& Laguerre, J. H. G. (1836-1952). La Presse. Paris: S.N. http://gallica.bnf.fr/ark:/12148/bpt6k543354z/texteBrut

Goody, J. (1977). The Domestication of the Savage Mind. Cambridge: Cambridge University Press.

Gordon, P., \& Lawton, D. (1978). Curriculum Change in the Nineteenth and Twentieth Centuries. London: Hodder \& Stoughton.

Graham, F. S. (1966). Government and Mission Education in Northern Nigeria 1900-1919, with Special Reference to the Work of Hanns Vischer. Ibadan: Ibadan University Press.

Gramsci, A. (1971). Selections from the Prison Notebooks. New York: International Publishers.

Hadow, W. H. (1923). Differentiation of the Curriculum for Boys and Girls. Report of the Consultative Committee. London: HMSO.

Hailey, L. (1938). An African Survey. A study of problems arising in Africa, south of the Sahara, $1^{\text {st }}$ ed. Oxford University Press.

Hardy, G. (1917). Une conquête morale: l'enseignement en A.O.F. Paris: A. Colin.

Harmand, J. (1910). Domination et colonisation. Paris: Flammarion.

Herder, J. G. (1783). Briefe zu Beförderung der Humanität. Germany: Bong.

Hetherington, P. (1978). British Paternalism in Africa, 1920-1940. London: Frank Cass.

Heyman, R. D., Lawson, R. F., Robert, M., \& Stamp, R. M. (1972). Studies in Educational Change. Toronto: Holt, Rinehart and Winston of Canada Ltd.

Hill, J. H. (1998). Today there is no respect': Nostalgia, 'respect', and oppositional discourse in Mexicano (Nahuatl) language ideology. In B. B. Schieffelin, K. A. Woolard, and P. V. Kroskrity (Eds.), Language Ideologies: Practice and Theory (pp. 68-86). Oxford: Oxford University Press.

Ihims, J. A. (2003). A Century of Western Education in Cameroon: A Study of its History and Administration (18441961). Bamenda: Unique Printers.

Innes, J. (1987). Jonathan Clark, Social History and England's 'Ancien Régime'. Past and Present, 115(1), 165-200. http://dx.doi.org/10.1093/past/115.1.165

Irvine, J. T. (1989). When talk isn't cheap: language and political economy. American Ethnologist, 16(2), 248-267. http://dx.doi.org/10.1525/ae.1989.16.2.02a00040

Jaffe, A. M. (1999). Ideologies in action: language politics on Corsica. Berlin: Mouton Walter de Gruyter. http://dx.doi.org/10.1515/9783110801064

Jaffe, A. M. (2001). Authority and authenticity: Corsican discourse on bilingual education. M. Heller and M. Martin-Jones (Eds.) Voices of Authority: Education and Linguistic Difference (pp. 269-296). Westport, Connecticut: Greenwood Publishing Group.

Johnson, W. R. (1970). The Cameroon Federation: Political Integration in A Fragmentary Society. Princeton: Princeton University Press.

Jones, C. (1995). A Language Suppressed: The Pronunciation of the Scots Language in the 18th Century. Edinburgh: John Donald.

Jones, D. V., \& Martin-Jones, M. (2004). 'Bilingual education and language revitalization in Wales: Past achievements and current issues'. 
http://dspace.trinity- cm.ac.uk/dspace/bitstream/10412/121/1/Bilingual\%20Ed.\%20final\%20version.pdf

Joseph, R. A. (1980). Church, state, and society in colonial Cameroun. The International Journal of African Historical Studies, 13(1), 5-32. http://dx.doi.org/10.2307/218370

Judge, A. (2007). Linguistic Policies and the Survival of Regional Languages in France and Britain. Basingstoke and New York: Palgrave Macmillan. http://dx.doi.org/10.1057/9780230286177

Kazadi, N. (1992). L'Afrique afro-francophone. Aix-en-Provence, Institut des études créoles et francophones. Paris: ACCT, Didier-Erudition.

Keller, W. (1969). The History of the Presbyterian Church in West Cameroon. Victoria, Cameroon: Presbook.

King, K. J. (1971). Pan Africanism and Education: a Study of Race, Philosophy and Education in the Southern States of America and East Africa. Oxford: Clarendon Press.

Kohn, M. (2012). Colonialism. In Edward N. Zalta (Eds.), The Stanford Encyclopaedia of Philosophy (summer Edition). Retrieved from http://plato.stanford.edu/entries/colonialism/

Konings, P., \& Nyamnjoh, F. B. (2000). Construction and deconstruction: Anglophones or Autochthones? The African Anthropologist, 7(1), 5-32.

Kouega, J. P. (2008). Minority language use in Cameroon and educated indigenes' attitude to their languages. International Journal of the Sociology of Language, 189, 85-113. http://dx.doi.org/10.1515/ijsl.2008.004

Lee, A., \& Schultz, K. A. (2012). Comparing British and French colonial legacies: A discontinuity analysis of Cameroon. Quarterly Journal of Political Science, 7(4), 1-46. http://dx.doi.org/10.1561/100.00011022

LeVine, V. T. (1964). The Cameroons: From Mandate to Independence. Berkeley: University of California Press.

Levy, P. (1929). Histoire linguistique d'Alsace et de Lorraine. Paris: Les Belles-Lettres.

Levy, P. (1950). La Langue allemande en France: De 1830 à nos jours. Lyon: IAC.

Lewis, M. P. (2009). Ethnologue: Languages of the World, Sixteenth edition. Dallas, Texas: SIL International. Online version: http://www.ethnologue.com/16.

Mahadeo, S. K. (1999). English - colonial to postcolonial: The problematics of writing in English in Mauritius. International Journal of language, Society and Culture, 4. Retrieved from http://www.educ.utas.edu.au/users/tle/JOURNAL/Articles/Mahadeo/Mahadeo.html

Mahmood, S. (1895). A History of English Education in India: Its Rise, Development, Progress, Present Condition and Prospects, Being a Narrative of The Various Phases of Educational Policy and Measures Adopted Under the British Rule from its Beginning to the Present Period (1781 to 1893). Alligarh: Muhammadan Anglo-Oriental College.

Mahwood, P. (1993). Applying the French model in Cameroon. In P. Mahwood (Eds.), Local Government in the Third World: The Experience of Decentralisation in Tropical Africa (pp. 177-188). Johannesburg: Africa Institute of South Africa.

Marchand, C. (1971). Idéologie coloniale et enseignement en Afrique noire francophone. Canadian Journal of African Studies, 5(3), 349-358. http://dx.doi.org/10.2307/484182

Mbala, O. R. (1986). L'École coloniale au Cameroun: approche historico-sociologique. Yaoundé: Ēditions de l'Imprimerie Nationale.

Mbassi-Manga, F. (1973). English in Cameroon: A Study of Historical Contacts, Patterns of Usage and Current Trends. Unpublished $\mathrm{PhD}$ thesis, University of Leeds.

Mbuagbaw, E. T. (2000). Language and Education in Cameroon: A Sociolinguistic Perspective. African Journal of Applied Linguistics, 1, 135-145.

McClintock, A. (1995). Imperial Leather: Race, Gender and Sexuality in the Colonial Contest. New York/London: Routledge.

Mufwene, S. S. (2005). Globalization and the myth of killer languages: What's really going on? In G. Huggan \& S. Klasen (Eds.), Perspectives on Endangerment (pp. 19-48). New York: Georg Olms Verlag.

Mwita, A. K. R. (2007). Secularisation of Mission education in Africa: A historical analysis with reference to Tanzania. Sadlier Lecture, University of Toronto, Wycliffe College.

Nana, G. (2013a). Children, Their Schools and What They Learn on Beginning Primary School: English and French 
Educational Legacies in Cameroon Schools. Newcastle Upon Tyne: Cambridge Scholars Publishing.

Nana, G. (2013b). 'This is No French School': Language and Education Traditions in Primary Schooling in Cameroon A Comparative Perspective. Research in Comparative and International Education, 8(4), 468-509. http://dx.doi.org/10.2304/rcie.2013.8.4.468

Neba, A. S. (1987). Modern geography of the Republic of Cameroon. Camden: Neba Publishers.

Ndi, A. (1986). The Second World War in Southern Cameroon and its Impact on Mission-State Relations. D. Killingray and R. Rathbone (Eds.), Africa and the Second World War 1939-50 (pp. 204-231). London: Macmillan Press.

Ndongko, W. A. (1986). The Political Economy of Development in Cameroon. Michael Schatzberg and I. William Zartman (Eds.), The Political Economy of Cameroon (pp. 83-110). New York: Praeger.

Ngijol, P. (1964). Nécessité d'une langue nationale. ABBIA, 7, 83-99

Nkwi, P. N., \& Warnier, J. P. (1982). Elements for a History of the Western Grassfields. Yaoundé: University of Yaoundé.

Nkwi, W. G. (2004). The Anglophone problem. In V. J. Ngoh (Eds.), Cameroon: from a Federal to a Unitary State, 1961-1972: a Critical Study (pp. 185-209). Limbe: Design House.

Nkwi, W. G. (2007). The Anglophone problem in Cameroon: towards new insights. In P. Fandio and M. Madini (Eds.), Figures de l'histoire et imaginaire au Cameroun/Actors of History and Artistic Creativity in Cameroun (pp. 153-160). Paris: L'Harmattan.

Nyamnjoh, F. B. (2012). Potted plants in greenhouses: A critical reflection on the resilience of colonial education in Africa. Journal of Asian and African Studies, 47(2), 129-154. http://dx.doi.org/10.1177/0021909611417240

O'Kelly, E. (1950). Eleven Delightful Years .Unpublished ms. Oxford: Rhodes House library, MSS Afr. S.889.

O'Neil, R. (1996). Imperialisms at the century's end: Moghamo relationships with the Bali-Nyonga and Germany 1889-1908. In I. Fowler and D. Zeitlyn (Eds.), African Crossroads: Intersections between History and Anthropology in Cameroon (81-100). Providence: Berghahn Books.

Orosz, K. J. (2008). Religious Conflict and the Evolution of Language Policy in German and French Cameroon, 1885-1939. New York: Peter Lang.

Patten, A. (2006). The Humanist Roots of Linguistic Nationalism. Retrieved from http://www.princeton.edu/ apatten/humanist-roots-jan06.pdf

Phillipson, R. (1996). Linguistic imperialism: African perspectives. ELT Journal, 50(2), $160-167$. http://dx.doi.org/10.1093/elt/50.2.160

PROPELCA. (1995). National Languages Education Programme in Cameroon. Yaoundé: Department of African Languages and Linguistics, University of Yaoundé I

Quinn, F. E. (1989). Rain Forest Encounters: The Beti Meet the Germans, 1887-1916. In M.Z. Njeuma (Eds.), Introduction to the History of Cameroon in the Nineteenth and Twentieth Centuries (88-105). London: MacMillan.

Quist, H. O. (2001). Cultural issues in secondary education development in West Africa: away from colonial survivals, towards neo-colonial influences? Comparative Education, 37(3), 297-314. http://dx.doi.org/10.1080/03050060120067794

Renou, X. (2002). A new French policy for Africa? Journal of Contemporary African Studies, 20(1), 5-27. http://dx.doi.org/10.1080/02589000120104035

Reynaud-Paligot, C. (2006). Usages coloniaux des représentations raciales (1880-1930). Cahiers d'histoire. Revue d'histoire critique, 9, 103-110. Retrieved from http://chrhc.revues.org/index813.html

Reynolds, D., Bellin, W., \& Ab Leuan, R. (1998). A competitive edge: Why Welsh medium schools perform better. Cardiff: Institute of Welsh Affairs.

Robinson, C. D. W. (1996). Language Use in Rural Development: An African Perspective. Berlin: Mouton de Gruyter. http://dx.doi.org/10.1515/9783110869040

Roger, L. (1967). Great Britain and Germany's Lost Colonies, 1914-1919. Oxford: Clarendon Press.

Rubin, N. (1971). Cameroun: An African Federation. New York: Praeger.

Rudin, H. R. (1938). Germans in the Cameroons, 1884-1914. A Case Study in Modern Imperialism. London: Jonathan 
Cape.

Samuelson, B. L., \& Freedman, S. W. (2010). Language policy, multilingual education and power in Rwanda. Language Policy, 9, 191-215. http://dx.doi.org/10.1007/s10993-010-9170-7

Shu, S. (1982). Education in Cameroon. In A. B. Fafunwa and J. Aisiku (Eds.), Education in Africa: A Comparative Survey (pp. 28-48). London: George Allen and Unwin.

Sinclair, M. E. (1976). Education, relevance and the community: A first look at the history of attempts to introduce productive work into the primary school curriculum. In K. King (Eds.), Education and Community in Africa. Edinburgh: Centre of African Studies.

Sirkin, G., \& Robinson, N. (1971). The battle of Indian education: Macaulay's opening salvo newly discovered. Victorian Studies XIV, 4, 407-428.

Sivonen, S. (1995). White-Collar or Hoe Handle? African Education under British Colonial Policy $1920-1945$. Helsinki: Suomen Historiallinen Seura.

Sow, A. (2008). Le profil de l'écolier noir à travers la literature coloniale. Liens, (11 décembre), 1-12.

Spens, W. (1938). Secondary Education with Special Reference to Grammar Schools and Technical High Schools. Report of the Consultative Committee. London: HMSO.

Stumpf, R. (1979). La politique linguistique au Cameroun de 1884 à 1960. Berne: Peter Lang.

Tabi, M. J. (2000). Les politiques linguistiques du Cameroun: Essai d'aménagement linguistique. Paris: Editions Karthala.

Tadadjeu, M. (1975). Language planning in Cameroon: Towards a trilingual education system. Patterns in Language, Culture and Society: Sub-Saharan Africa, Colombus, Ohio State University, Working Papers in Linguistics, 19, 53-75.

Tadadjeu, M. (1990). Le Defi de Babel au Cameroun. Yaoundé: University of Yaoundé.

Tangwa, G. B. (1999). Colonialism and linguistic dilemmas in Africa: Cameroon as a paradigm. Quest XIII, 1-2, 03-17

Tchombe, T. M. (2001). Structural reforms in education in Cameroon. Unesco unpublished policy paper.

Thomas, G. (2001). Why do we need the White Man's God? African contributions and responses to the formation of a Christian movement in Cameroon, 1914-1968. Unpublished Ph.D. thesis, University of London.

Todd, L. (1982). English in Cameroon: Education in a multilingual society. In J. B. Pride New Englishes (pp. 119-137). Rowley, MA: Newbury House. http://dx.doi.org/10.1075/veaw.t1

Todd, L. (1983). Language options for education in a multilingual society: Cameroon. C. Kennedy (Eds.), Language Planning and Language Education (pp. 160-171). London: George Allen and Unwin.

Toh, N. P. (2001). The Anglophone problem: Prospects for non-violent transformation. Bamenda: self-published.

Trevelyan, G. O. (1909). The life and letters of Lord Macaulay. London: Longmans, Green and Co.

Trudell, B. L. (2004). The Power of the local: Education choices and language maintenance among the Bafut, Kom and Nso' communities of northwest Cameroon. Unpublished Ph.D. Thesis, University of Edinburgh.

Twahirwa, A. (1994). Politiques et pratiques linguistiques en Afrique: Rapport d'un travail réalisé pour l'UNESCO. Paris: UNESCO, Division of Arts and Cultural Life.

UNESCO. (1953). The Use of vernacular languages in education. Monograph on fundamental education VIII. Paris: UNESCO.

Vernon-Jackson, H. O. H. (1967). Language, Schools, and Government in Cameroon. New York: Columbia University Teacher's College Press.

Vernon-Jackson, H. O. H. (1968). Schools and School Systems in Cameroon, 1844-1961. Columbia: Columbia University.

Vischer, H. (1915). Native education in German Africa. Journal of the African Society, 14(54), $123-142$.

Viswanathan, G. (1998). Masks of Conquest: Literary Study and British Rule in India. Oxford: Oxford University Press.

Walther, D. J. (2006). Le Malentendu Colonial. African Studies Review, 49(3), 187-188. http://dx.doi.org/10.1353/arw.2007.0072

Ward, W. E. F. (1953). African education: A study of educational policy and practice in British tropical Africa. Oxford: 
Oxford University Press. Retrieved from:

https://archive.org/stream/africaneducation013111mbp/africaneducation013111mbp_djvu.txt

Weber, C. W. (1993). International Influences and Baptist Mission in West Cameroon: German-American Missionary Endeavour under International Mandate and British Colonialism. Leiden: E. J. Brill.

White, B. W. (1996). Talk about school: education and the colonial project in French and British Africa, (1860-1960). Comparative Education, 32(1), 9-25. http://dx.doi.org/10.1080/03050069628902

Whitehead, C. (1995). The medium of instruction in British Colonial education: a case of cultural imperialism or enlightened paternalism? History of Education, 24(1), 1-15. http://dx.doi.org/10.1080/0046760950240101

Whitehead, C. (1999). The historiography of British imperial education policy, Part II: Africa and the rest of the colonial empire. History of Education, 24(1), 441-454.

Whitehead, C. (2000). Education in British colonial Africa 1919-1939'. In R. Lowe (Eds.), History of Education Vol. IV Studies of Education Systems (pp. 183-193). London and New York: Routledge and Falmer.

Whitehead, C. (2007). The concept of British education policy in the colonies 1850-1960. Journal of Educational Administration and History, 39(2), 161-173. http://dx.doi.org/10.1080/00220620701342296

Williams, R. (1961). The Long Revolution. London: Chatto and Windus.

Wilson, J. (1963). Education and Changing West African Culture. New York: Columbia University Teacher's College.

Wise, C. G. (1959). Plantation literacy classes. Overseas Education, 31(2).

Wolf, H. G. (1997). Transcendence of ethnic boundaries: The case of the Anglophones in Cameroon. Journal of Sociolinguistics, 1(3), 419-426. http://dx.doi.org/10.1111/1467-9481.00023

Wolf, H. G. (2001). English in Cameroon. Berlin: Mouton de Gruyter. http://dx.doi.org/10.1515/9783110849059

Woolard, K. (1998). Introduction: language ideology as a field of inquiry. B. B. Schieffelin, K. A. Woolard, and P. V. Kroskrity (Eds.), Language Ideologies: Practice and Theory (pp .03-47). Oxford: Oxford University Press.

Woolard, K., \& Schieffelin, B. B. (1994). Language ideology. Annual Review of Anthropology, 23, 55-82. http://dx.doi.org/10.1146/annurev.an.23.100194.000415

\section{Notes}

1.For a definition of colonialism and imperialism and their philosophical and economic underpinning (see Kohn, 2012; Curtin, 1974; McClintock, 1995; Boehmer, 2005).

2.This construct refers to the perception that a common language is fundamental to claims about nationhood.

3.In this context, the term used for nationality often refers to the language that the people of a given country speak.

4.Woolard and Schieffelin share Alan Patten's view regarding the origin of language ideology and its theorization as an instrument of social domination, colonial enterprise and political claim.

5.Nationalistic ambitions grounded in the use of a common German language and culture were, for instance, the major argument that prompted the annexation by Germany of France's regions of Alsace, Lorraine and Metz leading to the proclamation of the German Empire on the $18^{\text {th }}$ of January 1871. In opposition to the German argument of 'one nation, one language', France's contestation of the invasion of Alsace and Lorraine by Germany was based on the territorial integrity of the French state.

6.See the Ordinance of Villers-Cotterêts of the 10 August 1539, law No 94-665 of 4 August 1994, also known as la Loi Toubon and the statement in article 2 of the French constitution of 1958 that the language of the Republic shall be French. However, the constitutional revision of $23^{\text {rd }}$ of July 2008 introduced a new article, article 75-1, which recognizes regional languages as belonging to the patrimony of France.

7.See Jules Ferry's school laws of 1881 and 1882.

8.The King James' Version of the Bible is named after King James I of England who acceded to the English throne in 1603 but was formerly King James VI of Scotland.

9.Nonetheless, English contributed as an imperialist language to the suppression of the Irish language during the colonization of Ireland and to the suppression of any nationalistic claims based on Irish identities. This was also the case for Welsh in Wales and Scots in Scotland. These languages, especially Welsh, were seen as associated with backwardness and violence in the latter years of the nineteenth century. Education in the English language was viewed as a desirable form of intervention to combat these 'ills.' Children were compelled to receive education through the medium of English from the age of 5 and were punished if they were caught speaking Welsh at school, in the corridors 
and on the school playground (see Falls, 1997; Canny, 2003; Davies, 1999; Jones, 1995; Jones and Martin-Jones, 2004). 10.Shumum is the appellation of the Bamun language.

11.Breton and Fohtung argue that among the languages found in Cameroon, some were widely used than others due to the number of their speakers or because they served as languages of wider communication.

12.Pidgin English originated along the Cameroon coast around 1400 as a mixture of English, other European languages (such as Portuguese and Spanish) and Cameroonian languages and thus assumed the status of a lingua franca for trade.

13.Merrick, originally from Jamaica and influenced by the Jamaican experience of struggle against domination, introduced gospel singing in church and in school as a liberation tool for the colonized. The survival of gospel singing in Anglophone schools in Cameroon today is to be traced back to him (Cameroon movies director Teno, cited by Walther, 2006).

14.Fonlon (1969), Joseph (1980), Kouega (2008) and Todd (1983) point out that English was used in Baptist schools alongside some standardized Cameroonian languages.

15.English and Pidgin English also came to be established as the languages of court proceedings and of religion and gained influence along the Cameroon coast. Fonlon (1969) points out that the language used by the court of equity, established to settle trade disputes between local and European traders, was English. Major cases of trade disagreement were referred to the British Consul resident in Nigeria who often visited Douala. (See also Wolf, 1997, 2001).

16.This is the German rendering of Cameroon.

17.These authors suggest that the German colonial policy initially highlighted exploration over administration.

18.Local chiefs who opposed the German colonial administration's demands regarding the supply of conscripted men and the collection of labour tax faced dethronement, imprisonment or even death by execution, as in the case of Rudolf Duala Manga Bell.

19. With the advent of colonization, Basel and missionaries from other denominations were trained as evangelists of the colonies and thus served as agents of the colonial mission, working hand in glove with the various colonial administrations and traders to achieve this aim (see also http://missionaries.griffith.edu.au/missionary-training/basel-mission-society-1815).

20.With the arrival of these missionaries who used German in schools, English started losing its standing in education.

21.Now known as Limbe.

22. Hanns Visher, Director of Education for the Northern Provinces of Nigeria during the German era, highlights a divide between the home and the school in the early days of Cameroon's colonial history as education in German was equated to seeking a better life and in most cases far from the family in the village. Vischer subsequently became a member of both the Advisory Committee on Native Education in British Tropical Africa and the Phelps-Stokes Commission on Education in East African (see Graham, 1966).

23. While in the main the major Christian missions found in Cameroon before and during the German rule had some commitment to the use of local languages for instruction and the spread of the gospel, there is suggestion that the Catholic mission had no fixed language policy of their own and were mostly ready to cooperate with the German government or more practically, their choice and use of a language was dictated by the context (Wolf, 2001, p. 58).

24.That notwithstanding, the Basel Mission mainly focused on developing and using the Duala and Mungaka languages and ignored the promotion of other Cameroonian languages. By so doing, they belied, in a way, their avowed commitment to the value of each individual culture and language. Also, the use of only Duala and Mungaka languages in education by the Basel Mission was based on a political alliance between Douala kings Bell and Akwa and Gustav Nachtigal and that formed by the German commander, Zintgraff, with the Bali king which allowed an easy penetration of German expeditions into the Grassfields area (see Chilver, 1967).

25.Warneck was a nineteenth century missionlogist who believed in the value and uniqueness of each culture and thought that language, which according to him is the most noble creation of a people, should be used in school and the church.

26.Vernon-Jackson and Wolf note that there was a growing demand for German among the indigenous population and the language became popular among educated Cameroonians, while Visher indicates that the value of education was in its capacity to impact non-local knowledge useful for employment with the government or with Europeans.

27.In Basel Mission vernacular schools, only local languages, mostly Duala and Mungaka, were used and the record by Todd shows Basel Mission schools topping the list of number of schools and pupils' enrolment. This points to the 
popularity of these schools among the local population and their acceptance of education in a local language (see also Trudell, 2004, pp. 73-74).

28.The presence of the French and the British in the country is to be traced back to the start of World War I operations in 1914. On the mandate system and the trust territories (see DeLancey and DeLancey, 2000). As early as the 1950s, there was an independence advocacy for the colonies. In 1951, members of Southern Cameroon's political movements such as the Kamerun United National Congress and the Cameroons National Federation in alliance with the National Council of Nigeria and the Cameroons, were represented in Nigerian assemblies. A separate legislature was eventually created for the Southern British Cameroon in 1954 with Dr. E. M. L. Endeley as leader of the new House of Assembly. Endeley subsequently became the first prime minister of West Cameroon government on the 15 May 1958 but was replaced after elections in 1959 by John Ngu Foncha who led West Cameroon to reunification with French Cameroon (see Ardener and Ardener, 1996). In French Cameroon, there was also a move towards achieving self-governance with the constitution of parliamentary representation in 1946 through ARCAM (Assemblée Représentative du Cameroun). In 1952 ARCAM became ATCAM (Assemblée Territoriale du Cameroun) and in 1956, when the French government granted internal autonomy to French Cameroon, ATCAM was renamed ALCM (Assemblée Législative du Cameroun). On the 10 May 1957, André Marie Mbida became prime minister as a consequence of his party, PDC (Parti des Démocrates Camerounais) having the majority in the House of Assembly. However, Mbida was forced to resign in 1958 and was replaced by the vice-prime minister in charge of home affairs, Ahmadou Ahidjo, who led the country to independence.

29.With reference to British possessions in Cameroon, Gardinier argues that these strips of land were acquired simply to even out the Nigerian border as Britain had no intention of erecting a new and separate administrative unit in Cameroon. The Cameroon Province is present-day Northwest and Southwest Regions which during British colonial administration were divided into four divisions: Bamenda, Mamfe, Kumbo and Victoria.

30.With the establishment of British rule in the Cameroons, there was a German Mission Ordinance that banned missions of German obedience. In 1927, this ordinance was repealed by the Nigerian government and this allowed the return of former German Baptist missionaries and of confiscated properties to the German Missionary Societies.

31.Nonetheless, in Cameroon, the French colonial administration had an unusual collaboration with the church, given the secular option of the French state. This was perceived by some analysts as resulting from the fact that the French acquired Cameroon after anti-clericalism had ceased to be a major issue in French politics (see Johnson, 1970; Orosz, 2008). However, the overt favouritism of the Catholic Church over the Protestants, while translating a long-standing tradition of faith option in France, could also be interpreted as a way of limiting the sphere of German missionaries who were mostly Protestants, as the French administration conferred with its British counterpart on how to curb such influence. French colonial administration's preference for the Catholic Church is also indicative of the fact that the latter were keener to implement its assimilationist policy through the sole promotion of French in education than the Protestants who were reluctant to give up the teaching of local languages in schools and their use for the purpose of evangelization.

32. Whitehead (1999) argues that while there was agreement amongst colonial officials serving in the colonies and the colonial office in London about the need to adapt the curriculum in African schools and bring it into line with the local environment and culture, such agreement never involved the opinion of the colonized who mostly craved an English medium education rather than a vernacular curriculum.

33. At the imperial conference in 1926, L.S. Amery, the Colonial Secretary, pointed out that the British Government had as policy 'to substitute a purely literary education, which was really only suitable for the environment of somewhere like Great Britain, for a type of education that would give the native an understanding of his own environment and cultural setting'. British colonial administration's policy of 'education for life' significantly differed from the literary and evangelistic education so far offered by missionaries to the Africans.

34.The Privy Council Office, Miscellaneous Pamphlets, No. 1, 2.

35.Report of Commission III of the World Missionary Conference (1910), 277. The adaptation policy was implemented in the training of African-Americans at the Normal and Agricultural Institute at Hampton, Virginia, and the Normal and Industrial School at Tuskegee, Alabama.

36.Jones was the director of the Phelps-Stokes Fund.

37.The constitution of the Phelps-Stokes Commission was on the initiative of the Baptist Foreign Missionary Society in America which expressed the need for a study of African education through the Foreign Missions Conference of North America.

38.There is suggestion that through the two Phelps-Stokes Commissions the ideological and racial assumptions, 
implications, and controversies that surrounded education of African-Americans in America were transported to Africa. 39.Jesse Jones took part in the conference.

40.The Memorandum was written by J. H. Oldham who was the Secretary of the International Missionary Council.

41.The interest and implication of missionary bodies in African education had an impact on educational policy in British colonies in Africa and beyond.

42.ACNETA stands for Advisory Committee on Native Education in Tropical Africa.

43.(ACNETA, 1925, p. 4).

44.Drawing from various sources, including the Phelps-Stokes Reports, HannsVisher, a linguist, tabled this memorandum on the benefit of mother tongue use in the early years of education. For a copy of Visher's memorandum, see the file marked 'vernacular' in box 225 of The Joint IMC/CBMS Missionary Archives Africa and India 1910-1945 (Inter Documentation Co. Ag, Switzerland, 1979), as mentioned in Whitehead (1995, pp. 3-4). See also (ACNETA, 1925 , p. 6) for its recommendation on the study of vernaculars, their teaching and use in text books.

45. Whitehead indicates that it was chiefly due to the Indian experience that the growth of secondary education in Africa and elsewhere was so protracted during the 1930s. Also, see the Minutes of the Advisory Committee's first meeting of January 1924 for an advice from its chairman, Hon. W.G.A. Ormsby-Gore about avoiding in Africa the mistakes made in shaping educational policy in India. See Sir Christopher Cox Papers, National Archives, Kew, Ref. CO 1045/1, as mentioned in Whitehead (2007).

46.For a detailed account of views by Africans regarding vernacular education, see (Whitehead, 1995).

47.The place of the vernacular in native education, African No. 1110 (1927), 10-11, Colonial Office, as mentioned in Whitehead (1995, p. 11).

48.For a copy of the memorandum, see the file labelled 'Language Teaching' in box 223 of IMC/CBMS archives as cited in Whitehead (1995, p. 12). Mayhew was the new joint secretary of the Advisory Committee.

49.The report from non-African territories underlined the ineffectuality of trying to adopt a common policy for British colonies as a whole, as various policies applied to different situations. In fact, there were different government departments overseeing British colonial affairs around the world including the Indian Office, the Colonial Office and the Foreign Office.

50. Memorandum on language teaching in African education, 27 of November 1942, CO 1045/898 (Public Record office, Kew). The Memorandum was later printed for the use of the Colonial Office as African No. 1170, November 1943.

51. Nkwi and Warnier point out that the British colonial administration was seriously understaffed in the Cameroon Province and relied, mainly in the Grassfields, on the traditional authorities to govern for them. With the indirect rule policy becoming effective in 1922, 'the divisional officer governed the area through the chiefs, most of whom received stipends, especially the paramount rulers of Nso, Kom, Bali and Bafut'.

52.The German administration also used the services of local dignitaries to help it administer the territory.

53.The British Colonial government later introduced literacy education in English for its CDC workers and awarded scholarships to meritorious ones.

54.However, British investment during the colonial era was viewed as far more insignificant than French investment in the part of the country under French rule (see Ndongko, 1986). While British colonial policy is generally perceived of as laissez-faire, it is argued that in the Cameroonian case it bordered on neglect which resulted in the absence of railways, irrigation projects and shortage of roads (see Lee and Schultz, 2012).

55.As mentioned earlier, German missionaries were asked to leave after World War I and education was being run by military officers.

56.Nigerian and British army officials oversaw education in British Cameroons in the aftermath of World War I with little zeal for the project and few resources.

57.This was in keeping with the Phelps-Stokes Commissions' recommendations and the 1925 draft memorandum on the place of the vernacular in native education.

58.It is suggested that local languages were used as languages of instruction in the four first years of primary education while English was used during the last four years (Bitja'a Kody, 2003, p. 82; DeLancey and DeLancey, 2000, p. 30; Todd, 1982, p. 10, 1983, p. 163). 
59.Middle schools corresponded to the English secondary school.

60.Script communication was conducted in Hausa by the local or native administrations and federal and regional government departments used only English. British and Nigerian officers of all government departments were financially encouraged to pass language examinations in Hausa, Kanuri, or Fulani.

61.Military officers were in charge of schools in the aftermath of World War I and they were nearly all closed down when Britain started withdrawing her troops after the war.

62. Catechumenates were separate institutions for religious instruction.

63.Like Swiss and German Basel missionaries who were allowed to return to Cameroon Province, German Baptist missionaries also returned in 1926.

64.However, Native Administration schools and the vernacular schools established by the Basel Mission lacked resources and well trained teachers in the languages that they used.

65.The lack of teachers capable of teaching a local language suitable for the pupils made it impossible to introduce such language in government schools in Mamfe and Bamenda (British Government, 1927, p. 62).

66. Vernacular schools were rated in 1923 as facing disappearance. However, by 1929 there were more than 198 vernacular schools with 5,000 pupils as opposed to about 2,250 pupils attending officially registered schools (British Government, 1929, pp. 77-79).

67.The focus of these schools was mostly on religious instruction and indigenous language literacy.

68.The re-labelling and maintenance of vernacular schools came as a result of the intervention of provincial authority on behalf of the mission.

69.This was advocated by the Advisory Committee on Native Education.

70.They were allowed on the recommendation of the mission and the endorsement of the superintendent of education.

71.Presbyterian Education Authority, http://www.pccweb.org/education/education.htm.

72.Ibid.

73.Trudell suggests that the popularity of vernacular schools could come from their proximity to the communities and the fact that the school leadership was local. The schools could also have been viewed by the local population as a preschool before the move to English language schooling.

74.Ndi notes that more German than British nationals lived in the province and ran much of its commercial economy which employed about 25,000 people.

75.This gave the Catholic mission a lead over the other missions and it considerably improved its standing with the government during the war years.

76.Trudell observes that in 1942 the Mill Hill Mission, in their first language policy ever, decided to replace all its vernacular schools with English-medium schools and by 1943 all the Catholic schools in the province were in English. The German-American Baptists were also using English at that point.

77.The paramount ruler for the Nso Kingdom banned the use of Mungaka by the mission in Banso in 1938 and 1941.

78. However, Basel Mission's option for English as the medium of instruction could have been prompted by its perpetual conflict with colonial education authorities or by the resentment by other fractions of the Cameroonian population of its policy of only using Duala and Mungaka in its schools.

79.This was the second secondary school in the province which is today known as CPC Bali.

80.Bude argues that Cameroonians ignored the notion of adapted education as this neither provided the traditional European education, nor taught the children anything valued by the communities.

81.Only one mission secondary school existed in British Southern Cameroon in 1947 as compared to three government secondary schools in French Cameroon during the same year. In 1961, six such mission secondary schools existed in Southern Cameroon as opposed to twenty government secondary schools in East Cameroon. It is after 1961 that a government school opened in Southern Cameroon. This shows, as in the case of the German administration, the important role played in education by missionaries during the British rule. The missions were viewed by the British administration as a somewhat inexpensive way of implementing its policy and thought of as being better equipped than the government to shape the character of local youth.

82.Johnson points out that, anxious to save money, the colonial government allowed missionaries to monopolise educational and social provision and that almost 90 per cent of pupils in British Cameroons attended mission schools. 
83.Southern and Northern Cameroons were educationally respectively attached to the Northern and Eastern regions of British colonial Nigeria. Chiabi argues that British Cameroons was perceived as a place for incompetent or unambitious bureaucrats and there were complaints about the Lagos administration funds freezing and alienation of educational opportunities.

84.(See also article 22(6) of the League of Nations Covenant relating to colonial possessions cited earlier).

85.This policy was adopted on the suggestion of Félix Eboué, a colonial administrator in charge of French territories in central Africa.

86.Supposing, states the 1914 Study Plan, that the child, once back to family life, no longer uses the French language, it cannot be pretended that s/he is capable of wiping out of her/his mind the beneficial notions which, by the medium of that language, were inculcated in her/him: the words may go by, the ideas will remain, and those ideas that are ours, and whose use constitutes our moral, social and economic superiority, will slowly transform the barbarians of yesterday into disciples and auxiliaries (my translation).

87.Not only was French taught as a subject but it was considered essential that instruction in other subjects should be in French almost from the first day in school.

88.Lee and Schultz (ibid.) alleged that the nationalist movement in French Cameroon was led by urban évolués rather than by the chiefs as was the case in British Cameroons.

89.Rubin notes that prestation remains an indignant shared memory for many Cameroonians.

90.LeVine points out that with prestation, the death rate averaged around 60 per thousand workers.

91.English already appeared as a dominant language even before the start of the German administration and the Germans relied on this language for the administration of the territory in the early days of their rule. It was rather easy for the British to continue with an administrative and educative system akin to their policy of relying on missionaries for education and local royalties for territorial administration.

92.No book nor booklet, no print nor manuscript foreign to education is to be introduced in school without the authorization of the Commissioner of the Republic. French is the only language used in schools. Teachers are forbidden from using local dialects with their pupils (My translation). The rendering of Ferry's decree into English in the paragraph following Cadre's quotation is as follows: Article 14: 'French only shall be in use in schools.' Article 16: 'No book nor booklet, no print nor manuscript foreign to education is to be introduced in school without the written authorization of the inspector of the academy.'

93.A report to the French Ministry of Colonies, annex to the 'Journal Officiel' of the 7 September 1921, page 43, highlighted the need for the colonized to be instructed in the language of the colonizer as this was a logical assumption derived from the sovereignty right over colonial possessions (see Mbala Owono, 1986, p. 77).

94.Transforming the primitive people of our colonies, making them as much as possible dedicated to our cause and useful to our endeavour, we have at our disposal very limited means, and the most efficient means is to take the native from childhood, getting him to associate with us assiduously and submitting to our intellectual and moral habits uninterruptedly for many years; in a word, to allow him access to schools where his mind is shaped to our intentions (My translation). See also (Sow, 2008).

95.There was, however, an exception in the northern part of the country where Arabic used there since the $15^{\text {th }}$ century was still being used in koranic schools.

96.Such elite are those advocating 'francophonie' today as a cultural, economic and political instrument.

97.Looking at the French and English colonial administrations' involvement in education in Cameroon, it becomes apparent that the French colonial administration's agenda in education was akin to a 'civilizing' mission of Cameroonians in stages, and educating indigenous children with the objective of making them both 'useful and willing to be used'.

98.Stumpf and Robinson argue that the policy of using local languages in schools seemed to have been overtaken by the desire of young people to have access to salaried jobs and by the deliberate lack of debate about local languages by the incoming independent government. Also, English medium of instruction was reinforced by the British colonial government in the last years of its rule.

99.National is understood here in the sense of local, found in the country and not in the meaning of nationalist ideology of 'one nation, one language'.

100.Fonlon had a diploma in Education from Oxford University, studied at La Sorbonne and gained his PhD from the National University of Ireland. He was a close advisor of President Amadou Ahidjo and occupied several ministerial 
positions between 1961 and 1970. In 1971 he left the government to join the University of Yaoundé where he became head of department of African Literature. He was an advocate of official bilingualism and national integration.

101.Tadadjeu and Essono however argue that national unity must be grounded in Cameroon's multicultural reality which rather heralds linguistic diversity. Essono views the eventual disappearance of Cameroonian languages as tantamount to the annihilation of the country's national personality.

102.However, the balance of power based on the linguistic and cultural hegemony of these former colonial powers in the context of Africa and particularly of Cameroon appears to be shifting in favour of English (see Ager, 2001; Fonyuy, 2010; Mufwene, 2005; Samuelson and Freedman, 2010).

103.PROPELCA is to be praised for those advances as it has been canvassing since the 1970s for local languages to be introduced in schools in Cameroon. PROPELCA stands for 'Operational Research Project for Language Education in Cameroon' or 'projet de recherche opérationelle pour l'enseignement des langues au Cameroun' (PROPELCA, 1995).

104.See article 1, paragraph 3 of Cameroon's constitution of the $18^{\text {th }}$ of January 1996 and the Education Orientation Law $\mathrm{N}^{\circ} 004$ of the $14^{\text {th }}$ of April 1998.

105.Cameroon's shift in language in education policy appears to come as a result of the Language Plan of Action for Africa approved in 1986 by African heads of state and government during the $22^{\text {nd }}$ OAU ordinary session. The general purpose of the Language Plan of Action for Africa was to invite member states to initiate language policies that promoted African languages as official languages and media of instruction in schools and ensured a successful implementation of such policies (see part 1 of the Language Plan of Action for Africa for its aims, objectives and principles). Phillipson (1996) notes that the implementation of the Language Plan of Action for Africa is a bleak story. His observation is consequential to a survey of language legislation in most African countries commissioned for a UNESCO-OAU conference held in Addis Ababa in 1994 which highlighted awareness by African leaders of the need to the promote African languages and the importance of these in the general development of their countries as the sine qua non condition for a true take-off of an effective language policy for the continent.

106.Such resilient colonial and colonizing epistemology was evident in the classes that I observed during fieldwork for my $\mathrm{PhD}$ research where teachers refused to shift from an institutionalized linguistic paradigm to accommodate the use of pupils' mother tongue in school.

107.In 2001 the United Kingdom ratified the European Charter for Regional or Minority Languages in respect of Welsh in Wales, Irish in Northern Ireland and other languages of the UK such as Cornish, Scots and Scottish Gaelic. France, a signatory to the European Charter for Regional or Minority Languages, is yet to ratify it due to the statement in its constitution that French is the only official language of the republic. However, on the $28^{\text {th }}$ of January 2014, the country's National Assembly voted in favour of the Charter's ratification. Nonetheless, the mention of this Charter in the constitution might require that a referendum be called regarding the upholding or not of French as official language. This referendum could be circumvented if a congress of the French National Assembly and the Senate were to approve a constitutional bill for the insertion of the Charter in the constitution. Meanwhile, due to parents' pressure in the 1970s, the state created bilingual schools in some regions of France where French and a regional minority language were taught to an equal number of hours. Costa and Lambert (2009) indicate that in 2008-2009, there were over 57000 pupils in bilingual education at the primary level, 70 per cent of which were in the public system. 